\title{
EL GÉNERO CYPELLA (IRIDACEAE) EN URUGUAY
}

\author{
Leonardo Paz Deble ${ }^{1}$, Andrés González ${ }^{2}$ (iD \& Fabiano da Silva Alves ${ }^{1,3}$ (iD
}

\begin{abstract}
${ }^{1}$ Núcleo de Estudos Botânicos Balduino Rambo, Universidade Federal de Santa Maria, Santa Maria, 97105-900 Rio Grande do Sul, Brasil.

${ }^{2}$ Departamento de Botánica. Museo Nacional de Historia Natural (MNHN), Ministerio de Educación y Cultura; 25 de mayo 582, Montevideo,Uruguay; andres260390@gmail.com (autor corresponsal).

${ }^{3}$ Curso de Ciências Biológicas, Universidade da Região da Campanha, Praça Getúlio Vargas 47, Alegrete, $97542-570$ Rio Grande do Sul, Brasil.
\end{abstract}

\begin{abstract}
Deble, L. P.; A. González \& F. da S. Alves. 2021. The genus Cypella (Iridaceae) in Uruguay. Darwiniana, nueva serie 9(1): 173-208.

The genus Cypella is studied for the Uruguayan Flora. Based in revision of Herbaria and collections sampling were recognized 13 species and five subspecies for the country: C. alonsoana, C. aurinegra subsp. aurinegra, C. aurinegra subsp. albipurpurata, C. charruana, C. discolor, C. exilis, C. fucata, C. guttata, C. herbertii subsp. herbertii, C. herbertii subsp. brevicristata, $C$. herbertii subsp. reflexa, C. laeta, C. laxa, C. luteogibbosa, C. osteniana and C. rivularis. Cypella aurinegra subsp. albipurpurata comprises a new subspecies endemic in rocky place, on Mountain Range in Cerro Largo Department, Northeast Uruguay. Cypella laxa is a new record for the country. It is supplied dichotomous key, descriptions, material examined, comments and photos for all taxa identified. Furthermore, ecological data, conservation status, excluded species and other taxa with possible occurrence in Uruguay are listed.
\end{abstract}

Keywords. Bulbous; geophyte; grasslands; taxonomy; Tigridieae.

Resumen. Deble, L. P.; A. González \& F. da S. Alves. 2021. El género Cypella (Iridaceae) en Uruguay. Darwiniana, nueva serie 9(1): 173-208.

El género Cypella es investigado para la Flora Uruguaya. Basado en revisión de herbario y estudios en el campo fueron reconocidas 13 especies y cinco subespecies de Cypella: C. alonsoana, C. aurinegra subsp. aurinegra, C. aurinegra subsp. albipurpurata, C. charruana, C. discolor, $C$. exilis, C. fucata, C. guttata, C. herbertii subsp. herbertii, C. herbertii subsp. brevicristata, C. herbertii subsp. reflexa, C. laeta, C. lapidosa, C. luteogibbosa, C. osteniana y C. rivularis. Cypella aurinegra subsp. albipurpurata consiste en una nueva subespecie endémica en locales rocosos de las serranías del Departamento de Cerro Largo. Cypella laxa es un nuevo registro para el país. Se presenta clave dicotómica, descripciones, material examinado, comentarios y fotos para todos los taxones. Además, observaciones ecológicas, estado de conservación, especies excluidas y otros taxones con posible presencia en Uruguay son comentados.

Palabras clave. Bulbosas; geófitas; pastizales; taxonomía; Tigridieae. 


\section{INTRODUCCIÓN}

Cypella Herbert es un género de la tribu Tigridieae de la familia Iridaceae con 31 especies y cinco subespecies reconocidas, que habitan casi que exclusivamente en los pastizales del sureste de América del Sur (Deble \& Alves, 2020). El número de taxones válidos puede cambiar de acuerdo con las distintas interpretaciones de los límites genéricos de Cypella que es dado por diferentes autores. Por ejemplo, Roitman \& Castillo (2007), Goldblatt \& Manning (2008) o Roitman et al. (2008) dan un concepto amplio para el género y subordinan a él los géneros Phalocallis Herbert, Kelissa Ravenna y Onira Ravenna. Este criterio es seguido en el World Checklist de Iridaceae (WCI) (Barker, 2020). Chauveau et al. (2012) evidencian Cypella sensu lato como polifilético y tratan como segregados los géneros Hesperoxiphion Baker, Larentia Klatt y Phalocallis, además reconocen Kelissa, Onira y Cypella hauthalii (Kuntze) R.C. Foster como pertenecientes a un grupo aislado de las demás especies.

Los primeros estudios de iridáceas con material proveniente de Uruguay se remontan a trabajos clásicos elaborados desde inicio del siglo XIX, entre ellos se citan Sweet (1822) que describió Herbertia pulchella Sweet a partir de colecciones obtenidas por Anderson en Maldonado. Klatt (1862) en su obra "Specimen e familia Iridacearum" detalló algunos taxones basándose en colecciones obtenidas por Sellow en Uruguay y posteriormente en 1871, elaboró las claves y descripciones de las especies de Iridaceae presentes en la "Flora Brasiliensis", estudio que también vislumbró las especies uruguayas (Klatt, 1871). Baker (1877) en su "Systema Iridacearum" elaboró una propuesta de clasificación y descripción de las Iridaceae, contemplando diversas especies que habitan en Uruguay, refinando dicho trabajo en su "Handbook of Irideae" en 1892 (Baker, 1892). En este trabajo también presentó descripciones y claves para la identificación de los géneros y las especies de Iridaceae, siendo este trabajo utilizado hasta la actualidad para el reconocimiento de las especies presentes en Uruguay y Sudamérica en general.
Posterior a estos trabajos pioneros en la familia, han sido elaborados importantes estudios, entre los que se incluyen las publicaciones de Wright (1907) donde describió Herbertia amatorum Wright basado en colecciones realizadas por Cantera, Beauverd (1923) con Nouvelles Iridacées de l'Uruguay donde se describen nuevas especies de Sisyrinchium y Cypella osteniana Beauverd y Johnston (1938) quien describió numerosas especies de Sisyrinchium para el país en su trabajo "The species of Sisyrinchium in Uruguay, Paraguay and Brazil". Las contribuciones de Ravenna para el conocimiento de la familia en Sudamérica se han convertido en obras importantes para la identificación de las Iridaceae del Uruguay, ya que en muchas de estas publicaciones también fueron contempladas especies indígenas de Uruguay, varias de ellas nuevas para la ciencia, como es el caso de C. herbertii (Herb.) Herb. subsp. brevicristata Ravenna (Ravenna, 1965), C. fucata Ravenna (Ravenna, 1981b), Gelasine uruguaiensis Ravenna (Ravenna, 1984) y Herbertia quareimana Ravenna (Ravenna, 1989). Además, basado en Herbertia unguiculata Baker, Ravenna publicó el género monotípico Onira (Ravenna, 1983), con distribución en el norte de Uruguay y en el estado de Rio Grande del Sur, Brasil. Más recientemente nuevas citas y especies fueron adicionadas a la flora indígena de Uruguay, como el caso de Cypella laeta Ravenna (Roitman \& Castillo, 2004), la descripción de Calydorea alba Roitman \& A. Castillo (Roitman \& Castillo, 2005), Calydorea charruana Deble (Deble et al., 2013) y C. minuana Deble \& F.S. Alves (Deble et al., 2016), la tipificación de Cypella herbertii subsp. brevicristata (Deble \& Alves, 2017a) y la proposición de cuatro nuevas especies de Cypella: C. aurinegra Deble \& A. González y C. guttata Deble \& F.S. Alves (Deble et al., 2015a), Cypella charruana Deble \& F.S. Alves (Deble et al., 2015b) у C. alonsoana Deble \& F.S. Alves (Deble \& Alves, 2017b).

Comosepercibe, la familia es muyrepresentativa en Uruguay, evidenciado por la diversidad de especies conocidas, el número de taxones endémicos y la frecuencia de especies en la mayoría de las diferentes formaciones naturales del país. 
Esta diversidad es muy posiblemente debido a la localización geográfica del Uruguay y sus formaciones vegetales más características, compuesta por pastizales y ambientes de serranías o rocosos donde las Iridaceae son abundantes.

En esta revisión del género Cypella en Uruguay, discutimos la taxonomía, distribución geográfica, estado de conservación y límites de las especies principalmente con base en la observación de poblaciones en campo y de material de herbario. Se describen todas las especies estudiadas y se presentan comentarios sobre datos ecológicos, afinidades taxonómicas y conservación; además, suministran mapas de distribución geográfica, fotos y una clave para distinguir los taxones.

\section{MATERIALES Y MÉTODOS}

Se revisó toda la colección de los principales herbarios en Uruguay (MVFA, MVJB, MVM), así como de diversas instituciones en otros países incluyendo imágenes digitalizadas $(\mathrm{B}, \mathrm{CORD}$,
CTES, FCQ, FLOR, G, HAS, HBR, ICN, K, LP, NY, P, PACA, PY, R, RB, SGO, S, SI, SP, y US (según Thiers, 2020), donde pudieran encontrarse depositados especímenes recolectados en Uruguay. Además, fueron realizadas colecciones botánicas recientes para completar los datos de herbario en gran parte del territorio uruguayo. Las descripciones morfológicas tienen como base el material citado como examinado y la terminología adoptada sigue Ravenna (1981a, 1981b), Goldblatt \& Manning (2008) y Beentje (2010). Las figuras fueron elaboradas con base en ejemplares fotografiados en territorio uruguayo. Las especies fueron fotografiadas en ángulos para una mejor y práctica identificación.

Dado que la finalidad del trabajo fue la investigación del género Cypella en sentido estricto, fueron excluidos Phalocallis coelestis (Lehm.) Ravenna y Onira unguiculata (Baker) Ravenna, taxones con frecuencia referidos dentro del género Cypella. Las características morfológicas y su distribución en el Uruguay son detalladas en el ítem especies excluidas.

\section{RESULTADOS Y DISCUSÍON}

\section{Clave para el reconocimiento de los géneros de Iridaceae nativos del Uruguay}

1. Plantas rizomatosas. Hojas planas o cilíndricas Sisyrinchium

1. Plantas bulbosas. Hojas plicadas

2(1). Flores con ambas series de tépalos semejantes en forma, tamaño y color ................................................... 3

2. Flores con ambas series de tépalos desiguales en forma, tamaño y con frecuencia también en color ..................... 4 3(2). Filamentos libres. Plantas muy gráciles. Bulbo con catafilos marrón-oscuro o casi negro. Espatas bifloras. Flores pendientes. Hojas tenues, de 1-3 mm de ancho Calydorea 3. Filamentos totalmente soldados. Plantas robustas. Bulbo con catafilos anaranjados. Espatas 3-10-floras. Flores erectas. Hojas rígidas, de 10-30 $\mathrm{mm}$ de ancho Gelasine 4(2). Estilo con ramas filiformes en la base, plegadas y terminadas en crestas hacia el ápice; área estigmática dorsal, en una línea perpendicular a las crestas 5

4. Estilo con ramas filiformes sin crestas, área estigmática corta y terminal

5(4). Bulbos con catafilos marrón-pardusco, marrón-oscuro o casi negro. Espatas con brácteas internas más largas que las externas, convolutas. Tépalos internos con margen basal de la lámina glabra. Crestas 3, agudas Cypella 5. Bulbos con catafilos anaranjados. Espatas con brácteas internas y externas de igual longitud, naviculares. Tépalos internos con margen basal de la lámina densamente pilosa. Crestas 2 , redondeadas y petaloides Phalocallis 6(4). Perigonio urceolado; tépalos internos y externos con uñas bien desarrolladas, angostas Onira

6. Perigonio subcampanulado; tépalos internos y externos con uñas pequeñas y cuneadas 7

7(6). Tépalos internos con concavidad central muy oscura recubierta por tricomas lipídicos. Ramas del estilo cortamente bífidas o bífidas en el ápice Herbertia 7. Tépalos internos sin concavidad, tricomas lipídicos ausentes. Ramas del estilo emarginadas Catila 
Cypella Herbert, Botanical Magazine 53: t. 2637 (texto 2). 1826. Typus: Tigridia herbertii Herbert, Botanical Magazine 52: t. 2599. 1825.

= Polia Tenore, Cat. Orto Bot. Napoli: 92. 1845. Typus: Polia bonariensis Tenore, Catalogo Orto Botanico di Napoli: 92. 1845. [nom. illeg.], non Polia Louriero (1790).

Plantas pequeñas o medianas. Bulbos con catafilos marrón parduzco, marrón oscuro $\mathrm{o}$ casi negro, con raíces fibrosas y persistentes, no engrosadas. Tallos teretes o poco anguloso, angostos. Hojas basales ausentes o pocas en la antesis, angostamente lineares, lineares a linearensiformes, plicadas. Hojas caulinares envainando el tallo, las basales cuando presentes, elípticoensiformes y las más distales bracteiformes y envolviendo la parte basal de los pedúnculos. Sinflorescencia en ripidio ramificado o más raro fasciculiforme. Espatas uni o bifloras, herbáceas, verde-pálido, con dos valvas convolutas; valva externa mayor que la interna. Pedicelo filiforme, en general equilongo con la espata.
Flores radialmente simétricas, vistosas, amarillas, anaranjadas o blancas, con los tépalos formando una concavidad central. Tépalos disímiles, los externos obovado-oblongos u oblongos, patentes o reflejos, generalmente pandurados, base con uña cuneada, con tricomas glandulares escasos. Tépalos internos geniculado-recurvado $o$ ascendentereflejos, inclinados y después curvados arriba; láminas con tricomas lipídicos en depresión central; uñas angostamente cuneadas, con tricomas glandulares escasos. Filamentos en forma de cinta, obclavados o engrosados en ambas extremidades, libres o totalmente unidos formando una columna cónica; conectivo amplio, tecas negras, polen grisoscuro, ocráceo, amarillo o cian. Ovario oblongo u obovado, 3-locular, con numerosos óvulos. Estilo basalmente delgado y engrosado hacia el ápice donde se ramifica en 3 ramas plegadas. Ramas del estilo libres o unidas hasta la mitad de su longitud terminando en 3 crestas, dos adaxiales y una abaxial, con la región estigmática transversal en el dorso. Capsulas obovadas $\mathrm{u}$ oblongas, con numerosas semillas. Semillas angulares, marrón o rojizas, con epidermis estriada, doblada o más raramente lisa.

\section{Clave para la identificación de las especies uruguayas de Cypella Herbert}

1. Tépalos internos con unguículo más corto que la lámina, tricomas lipídicos dispuestos en una banda central en el tercio basal de la depresión central (sect. Cypella)

1. Tépalos internos con unguículo más largo que la lámina, tricomas lipídicos dispuestos en una banda central en la

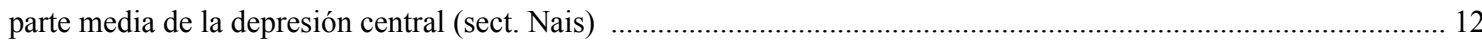

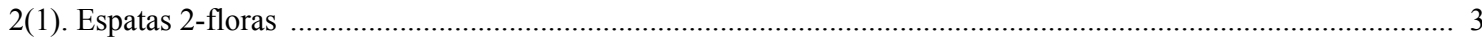

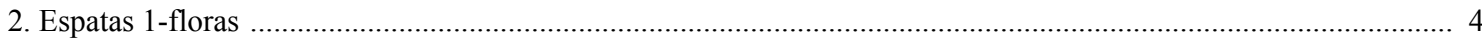

3(2). Plantas delicadas, de 10-25 cm de altura. Espatas 1,9-2,8 $\times 0,3-0,4 \mathrm{~cm}$. Perigonio predominantemente blanco o blanco-ocráceo, concavidad central 10-15 mm de diámetro C. osteniana

3. Plantas robustas, de 38-90 cm de altura. Espatas 3,1-4,5 × 0,4-0,6 cm. Perigonio predominantemente amarillo-dorado o anaranjado, concavidad central $18-23 \mathrm{~mm}$ de diámetro

C. alonsoana

4(2). Filamentos engrosados formando columna cónica, inclinada y más angosta en el ápice. Ramas del estilo muy gruesas y próximas, con la porción estigmática, casi tocándose una con la otra

4. Filamentos obclavados o acintados, erectos o declinados en el ápice. Ramas del estilo delgadas y separadas, con la porción estigmática distanciada una de la otra (excepto en C. fucata que tanto los ramos como la porción estigmática se tocan, entonces anteras de 3,2-4,5 mm de largo y filamentos muy delgados)

5(4). Perigonio de 34-40 mm de diámetro, amarillo-claro. Tépalos externos obovados, planos. Anteras y filamentos equilongos C. herbertii subsp. brevicristata

5. Perigonio de 40-55 mm de diámetro, amarillo, amarillo-dorado o anaranjado. Tépalos externos obovado-oblongos, con torcidos o recurvados. Anteras más largas que los filamentos

6(5). Estilo 9,5-11 mm de largo, base blanquecina y ápice purpuro-oscuro, terminando en crestas purpuro-oscuras en toda su extensión

C. herbertii subsp. herbertii 
6. Estilo 8,5-9,5 mm de largo, base amarillenta y ápice rojo o rojo-oscuro, terminado en crestas rojas en la base y amarillentas en el ápice C. herbertii subsp. reflexa

7(4). Anteras $>4,5 \mathrm{~mm}$ de largo

\section{8}

7. Anteras $\leq 4,5 \mathrm{~mm}$ de largo

8(7). Concavidad central con puntitos rojos o marrón-rojizos en toda su extensión. Filamentos acintados ......... C. guttata 8. Concavidad central con mancha marrón-oscura o marrón-rojiza en la base que se extiende hasta la mitad de la lámina. Filamentos obclavados C. exilis 9(7). Perigonio anaranjado-opaco. Ramas del estilo libres o unidas en la mitad inferior, terminado en crestas convergentes C. fucata

9. Perigonio blanco o amarillo. Ramas del estilo libres, terminando en crestas divergentes 10 10(9). Perigonio blanco o blanco-ocráceo; tépalos externos reflejos. Anteras 3-3,5 × 0,7-1 mm. Polen gris-azulado o cian. Semillas con epidermis reticulada C. luteogibbosa

10. Perigonio amarillo o blanco; tépalos externos patentes, con una mancha purpuro-oscura o purpura cerca de la base. Anteras 4-4,6 × 1,4-1,7 mm. Polen amarillo-ocráceo o casi negro. Semillas con epidermis lisa 11 11(10). Perigonio amarillo. Plantas de campos húmedos C. aurinegra subsp. aurinegra 11. Perigonio blanco. Plantas de campos pedregosos C. aurinegra subsp. albipurpurata 12(1). Espatas 2-floras. Perigonio amarillo-ocráceo C. laeta

12. Espatas 1-floras. Perigonio amarillo-anaranjado o blanco 13

13(12). Unguículo de los tépalos internos y externos similares en forma y tamaño. Tépalos externos abruptamente unguiculados, parte distal de la uña 4-5,5 $\mathrm{mm}$ de ancho C. charruana

13. Unguículo de los tépalos internos más angostos que los externos. Tépalos externos gradualmente unguiculados, parte distal de la uña 7-12 $\mathrm{mm}$ de ancho

14(13). Perigonio blanco o blanco-ocráceo. Anteras 5-6 mm de largo. Plantas de campos pedregosos, secos $C$. discolor 14. Perigonio amarillo. Anteras 7-9 mm de largo. Plantas de lugares encharcados

15(14). Tépalos firmes en textura; los externos con láminas punteadas con manchas marrón-rojizas. Anteras y filamentos equilongos C. rivularis

15. Tépalos tenues en textura, los externos con láminas lisas. Anteras dos veces más largas que los filamentos .... $C$. laxa

\section{Descripción de las especies}

\section{Cypella alonsoana Deble \& F.S. Alves, Kew} Bulletin 72 (3) 41: 2. 2017 (sect. Cypella). TIPO: Uruguay, Tacuarembó, Valle Edén, 24.X.2015, L. P. Deble \& A. S. de OliveiraDeble 15626 (holotipo SI!; isotipos CTES!, ICN!, K, PACA!). Figs. 1A-E y 2.

Plantas de $38-90 \mathrm{~cm}$ de altura, tallos subterráneos de 6-14 cm de largo. Bulbos 30-45 × 25-34 mm ovoides u obcónicos, prolongado en un collar de 3-6 cm de largo; catafilos angostamente elípticos, acuminados en el ápice, de color marrón claro, con líneas más oscuras en el dorso. Hojas basales en la antesis 2 a 6, láminas 32-48 × 0,3$0,5 \mathrm{~cm}$, angostamente lineares. Hojas caulinares basales 7,3-12,8 × 0,2-0,5 cm, elíptico-ensiforme, hasta $3 / 4$ del total de su largo envolviendo el tallo; hojas distales gradualmente menores 2,3-4,8 $\times$ 0,3-0,6 cm, ovado-lanceoladas. Ramas floríferas $34-79 \mathrm{~cm}$ de largo, ramas 2 a 5 . Espatas 1 a 3 por rama, 3,1-4,5 × 0,4-0,6 cm, herbáceas, verdes, 2-valvadas, 2-floras, pedunculadas, pedúnculos 2 , $1-6,5 \mathrm{~cm}$ de largo; valva externa $1,8-3,1 \mathrm{~cm}$ de largo, valva interna $3-4,4 \mathrm{~cm}$ de largo ambas obtuso-apiculadas en el ápice, y terminando en una parte hialina con líneas paralelas marrónoscuro; pedicelos filiformes, 3-4,8 cm de largo. Flores $35-45 \mathrm{~mm}$ de diámetro, perigonio amarillo-dorado o anaranjado, parte cóncava de las láminas con manchas púrpuras; concavidad central 18-23 $\mathrm{mm}$ de diámetro y $5-6 \mathrm{~mm}$ de profundidad. Tépalos externos 35-42 × 10-12 $\mathrm{mm}$, oblongos, pandurados, amarillos o amarillodorados, cóncavos en la base; láminas 22-30 × 16-22 mm, amarillo-doradas, con manchas rojas o marrón-rojizo en la base, patentes, revolutas, 


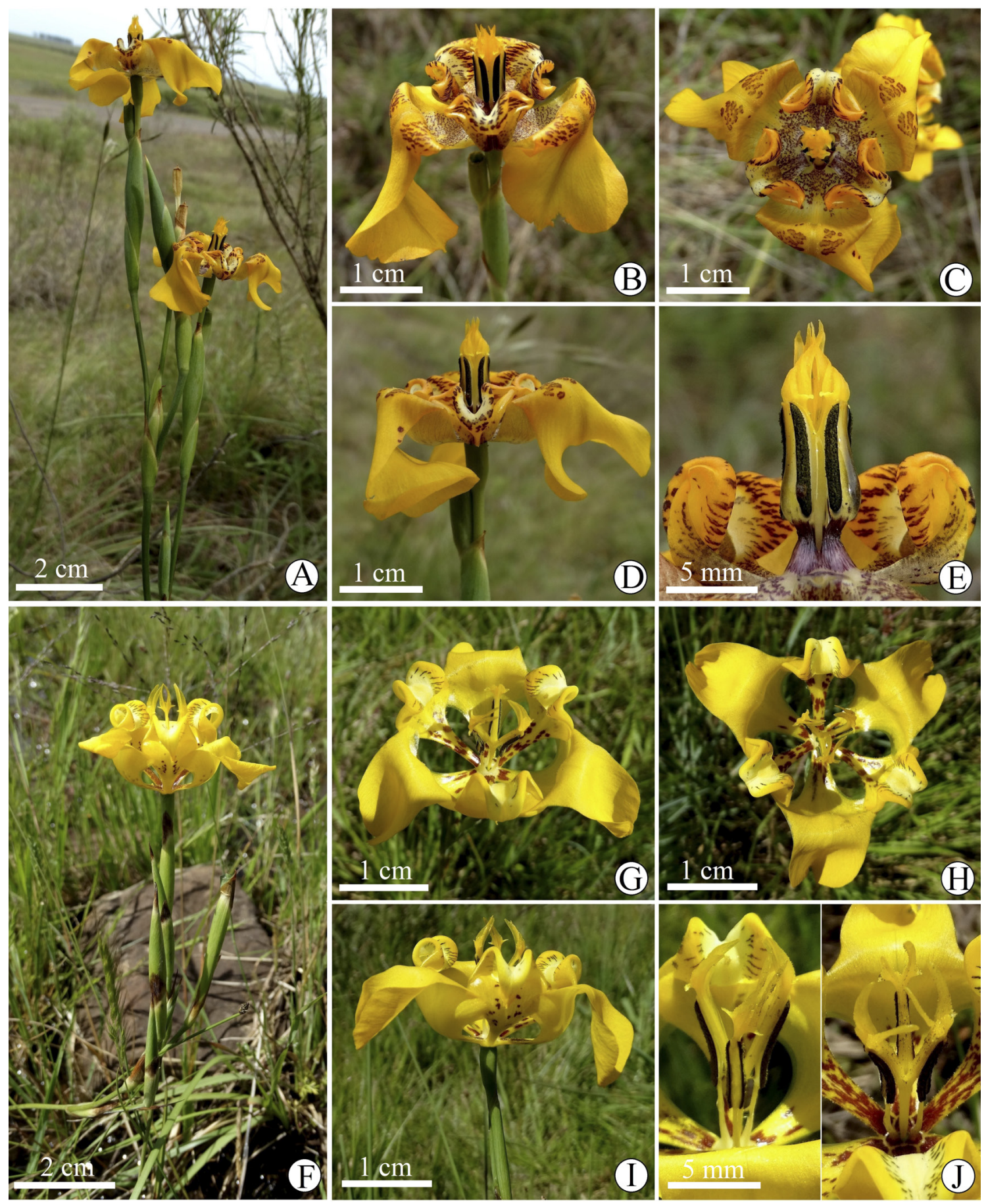

Fig. 1. Cypella alonsoana (A-E). A, rama en flor. B, flor, vista oblicua. C, flor, vista frontal. D, flor, vista lateral. E, detalle de estambres y estilo, en vista lateral. Cypella charruana (F-J). F, rama en flor. G, flor, vista oblicua. $\mathbf{H}$, flor, vista frontal. I, flor, vista lateral. J, detalle de estambres y estilo, en vista lateral y frontal. A-E, de Deble \& Oliveira 15626; F-J, de Deble et al. 15688. Figura en color en la versión en línea http://www.ojs.darwin.edu.ar/ index.php/darwiniana/article/view/921/1221 


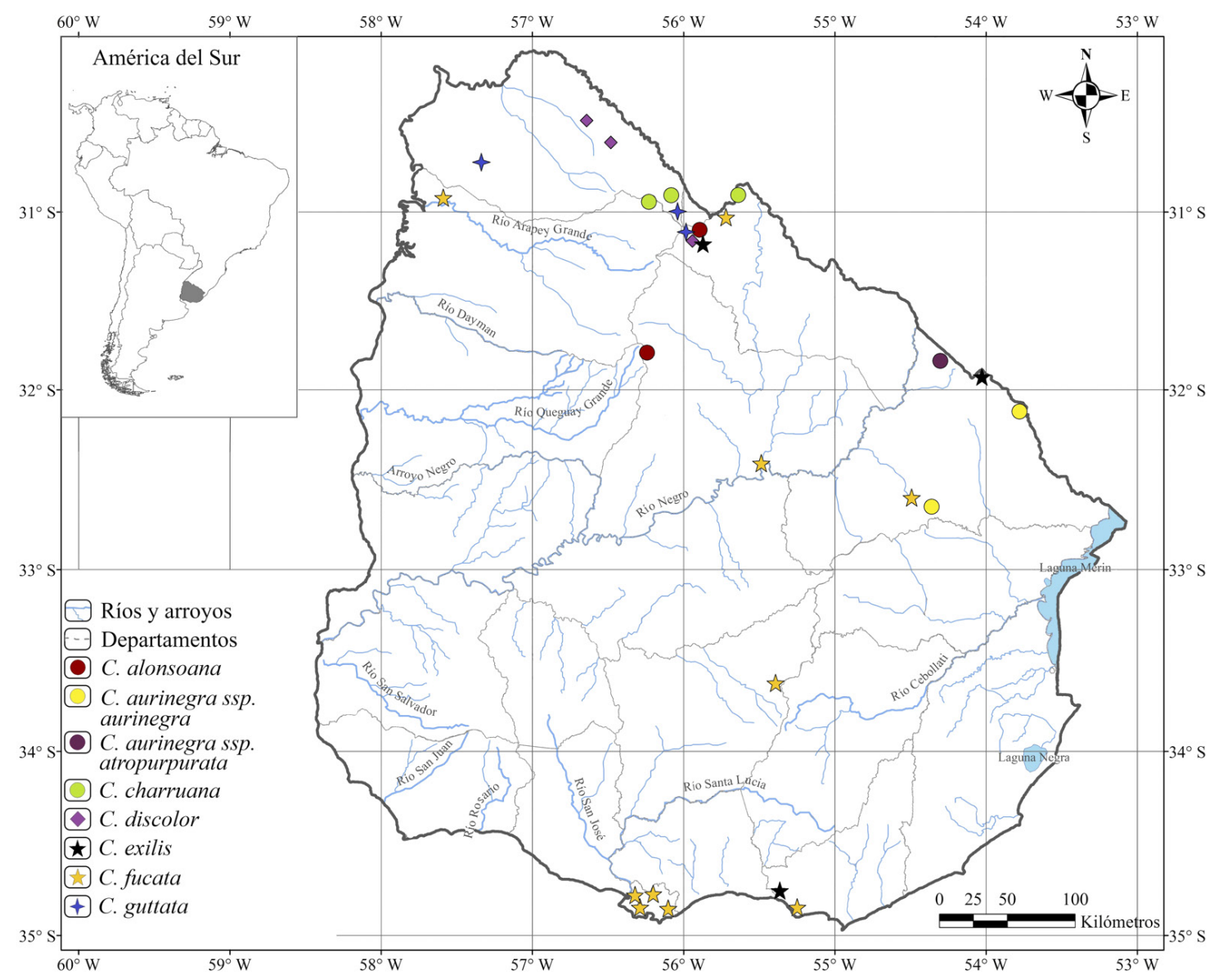

Fig. 2. Mapa de distribución de Cypella alonsoana, C. aurinegra subsp. aurinegra, C. aurinegra subsp. albipurpurata, C. charruana, C. discolor, C. exilis, C. fucata y C. guttata. Figura en color en la versión en línea http://www.ojs.darwin.edu.ar/ index.php/darwiniana/article/view/921/1221

ápice truncado o redondeado, apiculado, con dos manchas paralelas centrales y numerosos tricomas lipídicos entre las manchas; unguículo cuneado $10-12 \times 3,5-4 \mathrm{~mm}$ en la base y $12-15 \mathrm{~mm}$ de ancho en el ápice, amarillo, con abundante manchas marrón-rojizas. Tépalos internos 10-11× 11-12 mm, geniculado-recurvados, la mitad proximal patente, suavemente inclinada, después curvada arriba, con el tercio distal incurvado y fuertemente reclinado; láminas 11-12 $\mathrm{mm}$ de ancho, amarillo-doradas o anaranjadas, con una depresión central blanco-crema, cubiertos por tricomas lipídicos anaranjados en la base, con una parte lateral más alta, con líneas paralelas marrón rojizas y manchas irregulares; unguículo 4,5-5,5 ×
2,5-3 $\mathrm{mm}$ en la base y 5-5,5 $\mathrm{mm}$ ancho en el ápice, cuneado, amarillo dorado o anaranjado, con numerosas manchas marrón rojizas. Filamentos 2,2-2,8 $\mathrm{mm}$ de largo, acintados, levemente inclinados, marrones o púrpuras, base engrosada, blanco-crema, unidos en la base por 0,7-1 mm; anteras 5,5-6,3 × 2-2,6 mm, anchamente oblongas; conectivo 1,8-2,4 $\mathrm{mm}$ de ancho, amarillento, tecas oscuras, polen gris-oscuro u ocráceo. Ovarios 6-8 $\times$ 2-3 mm, oblongos, verdes. Estilos 6,5-7,5 mm de largo; ramas del estilo 2-2,8 $\mathrm{mm}$ de largo, ascendentes, unidas cerca de la $1 / 2$ del largo total; crestas en el ápice 3, amarillas, las adaxiales 3,84,6 $\mathrm{mm}$ de largo, lanceoladas, la abaxial 1,8-2 mm de largo, triangular. Cápsulas y semillas no vistas. 
Distribución geográfica y hábitat. Cypella alonsoana es conocida solamente para los puntos más elevados de los cerros y serranías de la Cuchilla Negra y Valle Edén en el norte de Uruguay donde crece entre los 200-300 metros sobre el nivel del mar en fisuras de rocas basálticas del Grupo Arapey, formación Los Catalanes, rellenas de arenisca de color rojizo de las formaciones Rivera y Tacuarembó (Bossi \& Navarro, 1988; Bossi \& Schipilov, 2007). Los individuos crecen asociados a la vegetación arbustiva característica de estos ambientes, como Acanthostyles buniifolius (Hook. \& Arn.) R.M. King \& H. Rob., Baccharis spicata Hieron., Baccharis vernicosa Hook. \& Arn., Hysterionica chamomilloides Deble, Radlkoferotoma berroi (Hutch.) R.M. King \& H. Rob., Lithraea molleioides (Vell.) Engl. y Schinus longifolius (Lindl.) Speg.

Etimología. Especie dedicada al botánico Uruguayo Eduardo Alonso Paz (1954-2016), quien fue investigador del Museo Nacional de Historia Natural de Montevideo y profesor de Botánica de la Facultad de Química de la Universidad de la República (Uruguay).

Observaciones. Cypella alonsoana se diferencia fácilmente de las demás especies del género por tener flores con perigonio amarillo o amarillodorado y espatas 2-floras. Otra observación interesante es que sus flores abren al mediodía y cierran hacia el fin de la tarde, mientras en las demás especies las flores son matutinas, manteniéndose excepcionalmente abiertas hasta el fin de la tarde (ver observaciones adicionales en C. fucata).

C. alonsoana es conocida únicamente para los ambientes de serranía de Cuchilla Negra y Valle Edén, donde se han ubicado solamente dos poblaciones con pocos individuos. De acuerdo con el número de poblaciones conocidas, número de individuos, la pérdida de la calidad de hábitat, expansión urbana y siguiendo los criterios de la IUCN (2019) la especie debe ser considerada como críticamente amenazada: CR B1, B2b, c + D.

\section{Material examinado}

URUGUAY. Rivera: Tranqueras, Cuchilla Negra, 1-XI-2015, L. P. Deble \& A. S. de OliveiraDeble 15645 (PACA!).

\section{Cypella aurinegra}

2.1. Cypella aurinegra Deble \& A. González subsp. aurinegra, Phytotaxa 236 (2): 102. 2015 (sect. Cypella). TIPO: Uruguay, Cerro Largo, Cañada Yerba Sola, " $11 \mathrm{~km}$ al norte de Puntas del Parao", 32॰ 37' 36”' S; 54 22' 51” W, 7.IV.2014, A. González 2250 (holotipo MVFA!). Figs. 3F-J y 2.

Plantas de 8-22 cm, tallo subterráneo de 2,5-6 cm. Bulbogloboso, $8-17 \times 7-15 \mathrm{~mm}$, prolongadoenuncollar de 2-4 cm; catáfilos anchamente ovados, acuminados en el ápice, de color marrón claro. Hojas basales en la antesis ausentes o hasta 2, lámina 7-15 × 0,05-0,2 cm, angostamente linear. Hoja caulinar más basal 2,5-4 $\times$ 0,1-0,3 cm, elíptico-ensiforme, con hasta $2 / 3$ del total de su largo envolviendo el tallo. Ramas floríferas 6-15 cm de largo, con 2 ramificaciones. Espatas 1-3 por rama, 2,4-2,8 $\times$ 0,2-0,3 cm, herbáceas, verdes, 2-valvadas, 1-flora, pedunculadas, pedúnculos $1,2-1,8 \mathrm{~cm}$; valva externa $1,2-1,5 \mathrm{~cm}$, valva interna 2,3-2,7 cm, ambas agudas en el ápice, y terminando en una parte hialina con líneas paralelas marrón-oscuro; pedicelo filiforme, 2-2,5 cm. Flores 28-36 mm diámetro, perigonio amarillo con manchas purpuro-oscuro; concavidad central 12-16 mm diámetro y 4-6 $\mathrm{mm}$ de profundidad. Tépalos externo 20-22 × 8-9 mm, oblongos, pandurados, amarillo, cóncavo en la base; láminas 12-14 × 7-7,5 mm, amarilla, con manchas purpuro-oscuro en la base, suavemente patentes, ápice truncado o redondeado, apiculado; unguículo anchamente cuneado, 7-8 $\times$ 1,5-1,9 $\mathrm{mm}$ en la base y 6,5-7,8 $\mathrm{mm}$ de ancho en el ápice, amarillo claro, translúcido, sin manchas. Tépalos internos geniculado-recurvados, 6-7 $\times$ 5,5-6 mm, la mitad proximal patente, suavemente inclinada, después curvada arriba, con el tercio distal incurvado y fuertemente reclinado; láminas $5-6,5 \mathrm{~mm}$ de ancho, amarilla, con una depresión central blancocrema, cubierto por tricomas lipídicos anaranjados en la base, con una parte lateral más alta, con líneas paralelas purpuro-oscuro y manchas irregulares; unguículo $5-5,5 \times 1,1-1,4 \mathrm{~mm}$ en la base y 3,2$3,7 \mathrm{~mm}$ ancho en el ápice, cuneado, amarillo-claro, translúcido, con líneas rojas paralelas. Filamento 2-2,5 $\mathrm{mm}$, angostamente obclavado, levemente inclinados, blanco-crema, base engrosada, unido por 0,3-0,4 $\mathrm{mm}$ en la base; anteras 4-4,4 × 1,4-1,7 mm, anchamente oblongas; conectivo 1,1-1,4 $\mathrm{mm}$ de 

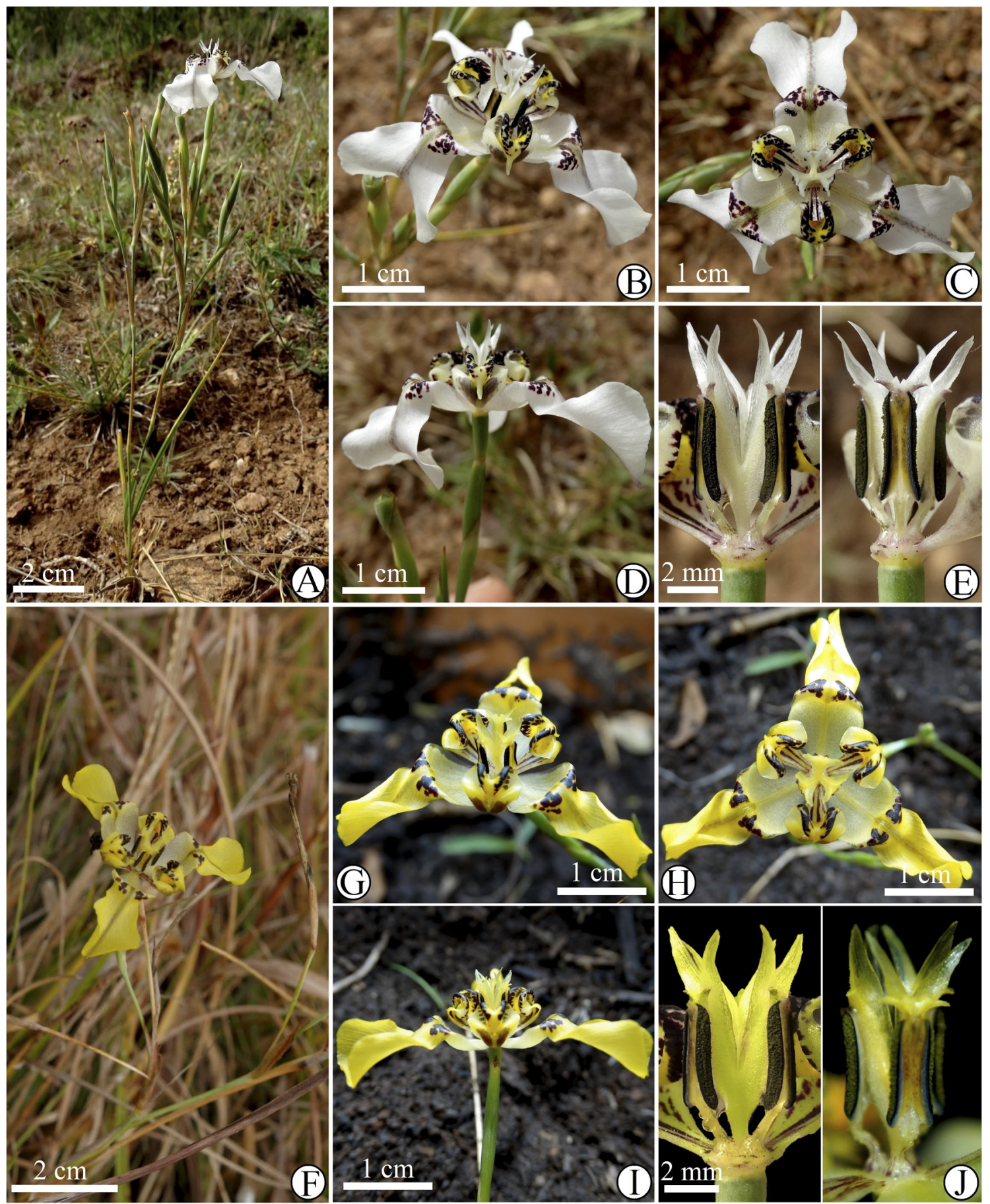

Fig. 3. Cypella aurinegra subsp. albipurpurata (A-E). A, hábito. B, flor, vista oblicua. C, flor vista frontal. D, flor, vista lateral. E, detalle de estambres y estilo. Cypella aurinegra subsp. aurinegra (F-J). F, ramo en flor. G, flor, vista oblicua. $\mathbf{H}$, flor vista frontal. I, flor, vista lateral. J, detalle de estambres y estilo, en vista lateral y frontal. A-E, de Deble \& Deble 17128; F, de González 2250; G-J, cultivado de semillas de Deble \& Oliveira 15105. Figura en color en la versión en línea http://www.ojs.darwin.edu.ar/index.php/darwiniana/article/view/921/1221 
ancho, amarillento, tecas oscuras, polen gris-oscuro u ocráceo. Ovario 3,5-4,5 mm $\times 1,8-2,2 \mathrm{~mm}$, verde, obclavado. Estilo 5,4-6 mm; ramas del estilo 3,5$4 \mathrm{~mm}$, ascendentes; crestas en el ápice 3, amarillas, las adaxiales 2,4-2,9 mm, lanceoladas, la abaxial 0,8$1,1 \mathrm{~mm}$, triangular. Cápsula 9-10 × 5,5-6 mm obovada, con puntitos y líneas glandulares, conteniendo 64-95 semillas. Semillas 2-2,5 mm largo, oblongas u obcónicas, marrón-claro, anguladas, epidermis lisa.

\section{Distribución geográfica y hábitat. Cypella} aurinegra subsp. aurinegra es endémica del departamento de Cerro Largo, encontrándose en la cuenca del río Tacuarí al sur del departamento y en el Paisaje Protegido Paso Centurión y Sierra de Ríos al noreste, donde la especie fue observada, sin embargo, no se han hecho colecciones por ser una especie amenazada. Se conocen pocas poblaciones que crecen en campos húmedos cerca de cursos de agua, desenvueltas sobre areniscas de la formación Tres Islas (Bossi \& Navarro, 1988) entre 80-150 m s.m., creciendo junto a Saccharum angustifolium (Nees) Trin., Paspalum notatum Flüggé, Axonopus fissifolius (Raddi) Kuhlm., Bothriochloa laguroides (DC.) Herter, Richardia humistrata (Cham. \& Schltdl.) Steud. y Oxalis sellowiana Zucc.

Etimología. Del latín aureus (= amarillo) y niger (= negro), en referencia a las flores con tépalos amarillos con manchas purpuro-oscuras, casi negras.

Observaciones. Cypella aurinegra subsp. aurinegra es fácilmente reconocible por sus flores amarillas con manchas purpuro-oscuras, casi negras. La especie puede ser confundida con $C$. fucata, de la que se diferencia por presentar flores amarillas vs anaranjadas y ramas del estilo libres vs unidas en la mitad inferior, además las semillas son parduscas y tienen epidermis lisa mientras en $C$. fucata las semillas son marrónrojizas y la epidermis es reticulada.

C. aurinegra subsp. aurinegra fue considerada Críticamente Amenazada (Deble et al., 2015a) por su hábitat restringido a campos húmedos junto a cursos de agua en el departamento de Cerro Largo.

\section{Material examinado}

URUGUAY. Cerro Largo: Arbolito, "Sources of Tacuari river, on wet grasslands" 22-IV-2014, $L$. P. Deble \& A. S. de Oliveira-Deble 15105 (SI!).
2.2 Cypella aurinegra Deble \& A. González subsp. albi purpurata Deble, subsp. nov. TIPO: Uruguay, Cerro Largo, Aceguá, Sierra de Aceguá, en rocas, muy escasa, flores blancas", 31 ${ }^{\circ} 51^{\prime} 14.90^{\prime \prime}$ S and 54 14 '8.73”'W, 11.XI.2018, L.P. Deble \& M.I.P. Deble 17128 (holotipo PACA!). Figs. 3A-E y 2.

Cypella aurinegra subsp. albipurpurata differs from $C$. aurinegra subsp. aurinegra by its more robust habit $15-35 \mathrm{~cm}$ vs $8-22 \mathrm{~cm}$, white perigone vs yellow and habitat, since $C$. aurinegra subsp. albipurpurata occurs in stony fields, with the bulbs growing in the rocks of granite origin at the highest points of the Mountains range of the north of the department of Cerro Largo, while $C$. aurinegra subsp. aurinegra grows in wet grasslands developing on sandstone at low points, in the springs of the water courses, south and northeast of the department of Cerro Largo. Cypella aurinegra subsp. albipurpurata differs from $C$. luteogibbosa Deble by flowers with outer tepals not recurved vs. recurved, stamens with filiform filaments, anthers 4,1-4,5 $\times$ 1,4-1,7 $\mathrm{mm}$ and dark-gray or dark ochraceous polen vs. obclavate filaments, anthers $3-3,5 \times$ 0,7-1 $\mathrm{mm}$ and grayish blue or cyan, and light brown seeds, with smooth epidermis vs. dark brown and faveolate epidermis.

Plantasde $15-35 \mathrm{~cm}$, tallosubterráneode $3,5-6 \mathrm{~cm}$. Bulbo 15-27 × 13-25 mm, globoso o depresogloboso, prolongado en un collar de $2-6 \mathrm{~cm}$; catáfilos anchamente ovados, acuminados en el ápice, de color marrón claro. Hojas basales en la antesis ausentes o hasta 2, lámina 5-18 $\times 0,2-0,3 \mathrm{~cm}$, linear. Hoja caulinar más basal 2,5-4 × 0,1-0,3 cm, elíptico-ensiforme, con hasta $2 / 3$ del total de su largo envolviendo el tallo. Ramas floríferas 11$30 \mathrm{~cm}$ de largo, ramas 2 a 3 . Espatas 1 a 3 por rama, 2,8-3,2 × 0,2-0,3 cm, herbáceas, verdes, 2-valvadas, 1-flora, pedunculadas, pedúnculos 0,6-1,4 cm; valva externa 1,5-2 cm, valva interna 2,8-3,1 cm, ambas agudas en el ápice, y terminando en una parte hialina con líneas paralelas marrón-oscuro; pedicelo 2,5-3,2 cm, filiforme. Flores 34-42 mm diámetro, perigonio blanco con manchas púrpuras; concavidad central 14-18 mm diámetro y 5-7 $\mathrm{mm}$ de profundidad. 
Tépalos externos 22-25 × 9-10 mm, oblongos, pandurados, blanco, cóncavo en la base; láminas $14-16 \times 7,5-8 \mathrm{~mm}$, blanca, con manchas purpuras en la base, suavemente patentes, ápice truncado o redondeado, apiculado; unguículo 8-9 × 1,5-2 mm, anchamente cuneado, en la base y $6,5-8 \mathrm{~mm}$ de ancho en el ápice, blanco-ocráceo, translúcido, sin manchas. Tépalos internos 6,5-7,5 × 6-6,5 mm, geniculado-recurvados, la mitad proximal patente, suavemente inclinada, después curvada arriba, con el tercio distal incurvado y fuertemente reclinado; láminas 6-6,5 $\mathrm{mm}$ de ancho, blanco-ocráceo, con una depresión central blanco-crema, cubierto por tricomas lipídicos anaranjados en la base, con una parte lateral más alta, con líneas paralelas purpuras y manchas irregulares; unguículo 5-5,5 $\times$ $1,1-1,5 \mathrm{~mm}$ en la base y 3,2-3,7 $\mathrm{mm}$ ancho en el ápice, cuneado, blanco, translúcido, con líneas rojas paralelas. Filamentos 2-2,5 mm, filiforme, levemente inclinados, blanco-crema, base engrosada, rosada, unido en la base por $0,3-0,4$ $\mathrm{mm}$; anteras 4,1-4,5 × 1,4-1,7 $\mathrm{mm}$, anchamente oblongas; conectivo 1,1-1,4 mm de ancho, blanco, tecas oscuras, polen gris-oscuro u ocráceo. Ovario 4,5-5 × 1,8-2,2 mm, verde, obclavado. Estilo 5,6$6,5 \mathrm{~mm}$; ramas del estilo 3,5-4 mm, ascendentes; crestas en el ápice 3 , blanquecinas, hialinas, las adaxiales 2,7-3 mm, lanceoladas, la abaxial 0,5$1 \mathrm{~mm}$, triangular. Cápsula 10-12 × 5,5-6 mm, obovada, con puntitos y líneas glandulares, conteniendo ca. 60 semillas. Semillas 2-2,5 mm largo, oblongas u obcónica, marrón-claro o marrónoscuro, anguladas, epidermis lisa.

\section{Distribución geográfica y hábitat. Cypella} aurinegra subsp. albipurpurata es endémica de Uruguay, encontrándose exclusivamente en el norte del departamento de Cerro Largo. Hasta ahora se conoce una población, que crece en las hendiduras de rocas graníticas (Elizalde et al., 1970; Preciozzi et al., 1985) a 250 m s.m. sobre las serranías al sur de la ciudad de Aceguá, junto con Calibrachoa pubescens (Spreng.) Stehmann, Frailea pygmaea Britton \& Rose, Herbertia pulchella, Hysterionica pinifolia (Poir.) Baker y Lippia arechavaletae Mold.

Etimología. Del latín albi (= blanco) + purpurata (= purpuro), en referencia a las flores con perigonio blanco con manchas purpuro o purpuro-oscuras.

Observaciones. Debido a su hábito más robusto y sus flores con perigonio blanco resulta fácil su reconocimiento frente a $C$. aurinegra subsp. aurinegra. Además, C. aurinegra subsp. albipurpurata habita en campos pedregosos, con los bulbos creciendo en las hendiduras de rocas de origen granítico en los puntos más elevados de las Serranías del norte del Departamento de Cerro Largo, mientras $C$. aurinegra subsp. aurinegra crece en campos húmedos en puntos bajos, al margen de cursos de agua al sur y noreste del departamento de Cerro Largo. Por el color de las flores y habito, C. aurinegra subsp. albipurpurata puede ser confundida con C. luteogibbosa; sin embargo, el hábito más robusto, las espatas mayores, la forma del perigonio, los estambres con anteras mayores y filamentos más delgados, los gránulos de polen parduscos u ocráceos (vs gris o cian) y las semillas con epidermis lisa son características morfológicas que pueden ser usadas para segregar ambos taxones.

C. aurinegra subsp. albipurpurata habita en los puntos más elevados de las Serranías del norte del Departamento de Cerro Largo, una región con actividades económicas de ganadería y minería, esta última actividad resulta una gran amenaza para $C$. aurinegra subsp. albipurpurata. Con base en la única población conocida, número de individuos y amenazas observadas se considera $C$. aurinegra subsp. albipurpurata como Críticamente Amenazada (CR B1, B2a,b,c + D) (IUCN, 2019).

3. Cypella charruana Deble \& F.S. Alves, Darwiniana, nueva serie, 3(2): 237. 2015 (sect. Nais).TIPO: Brasil, Rio Grande do Sul, Santana do Livramento, "on the border with Uruguay, in the spring of the Quaraí River, in the midst of native grassland in moist soil on volcanic rock from the Serra Geral geological formation", $30^{\circ} 57^{\prime} 44.34$ ' S, 55 $5^{\circ} 43$ ' 33.68", W, 15.XI.2014 (fl, fr), L. P. Deble, A. S. de Oliveira-Deble \& F. S. Alves 15108 (holotipo SI!; isotipo PACA!). Figs. 1F-J y 2. 
Plantas de 20-40 cm, tallo subterráneo de 5-12 cm. Bulbo 25-35 × 20-35 mm, globoso u ovoide, prolongado en un collar de $4-10 \mathrm{~cm}$; catáfilos anchamente ovados, truncados hasta acuminados en el ápice, de color marrón oscuro. Hojas basales en la antesis 2 a 6, lámina 14-26 × $0,2-0,5 \mathrm{~cm}$, linear-ensiforme. Hoja caulinar 3,5$9,5 \times 0,1-0,5 \mathrm{~cm}$, bracteiforme, con hasta $2 / 3 \mathrm{del}$ total de su largo envolviendo el tallo. Ramas floríferas 7-14 cm de largo, ramas 2 a 3. Espatas 1 a 3 por rama, 3,2-3,8 $\times 0,4-0,5 \mathrm{~cm}$, herbáceas, verdes, 2-valvadas, 1-flora, pedunculadas, pedúnculos 1,4-2,8 cm; valva externa 1,7-2,5 cm, valva interna $3-3,5 \mathrm{~cm}$, ambas agudas en el ápice, y terminando en una parte oscura, con líneas paralelas marrón-oscuro; pedicelo 3-3,5 cm, filiforme. Flores 40-55 mm diámetro, perigonio amarillo o amarillo-dorado con manchas purpuro-oscuro; concavidad central $30-38 \mathrm{~mm}$ diámetro y $18-25 \mathrm{~mm}$ de profundidad. Tépalos externos 34-40 × 14,5-19 $\mathrm{mm}$, oblongos, pandurados, amarillos o amarillo-dorados, cóncavo en la base; láminas 20-28 × 15-19 mm, amarillas o amarillo-doradas, erectas en el tercio basal y revolutas en el ápice, truncado o redondeado, apiculado; unguículo 11-14 $\mathrm{mm} \times$ 2-2,5 $\mathrm{mm}$ de ancho en la base y 4-5,5 $\mathrm{mm}$ de ancho en el ápice angostamente cuneado, amarillo, poco translúcido, con manchas marrón-rojizas. Tépalos internos 22-28 × 7,5$10 \mathrm{~mm}$ arqueado-recurvados, la mitad proximal inclinada, después curvada arriba, con el tercio distal incurvado y fuertemente reclinado; láminas 7,5-10 $\mathrm{mm}$ ancho, amarillas, con una depresión central blanco-crema, cubierta por tricomas lipídicos anaranjados, con una parte lateral más alta, con líneas paralelas purpurooscuro y manchas irregulares; unguículo 10-11 $\times$ 1,8-2,2 $\mathrm{mm}$ en la base y 4-5 $\mathrm{mm}$ ancho en el ápice, angostamente cuneado, amarillo-claro, con líneas y manchas marrón-rojizas. Filamento 8,4-10,5 mm, delgado, filiforme, levemente inclinados, blanco-crema o amarillento, base engrosada, unidos en la base por 0,5-0,8 mm; anteras $8-9,5 \times 1,4-1,8 \mathrm{~mm}$, angostamente oblongas; conectivo 0,4-0,5 $\mathrm{mm}$ de ancho, amarillento, tecas oscuras, polen gris-oscuro, ocráceo o anaranjado. Ovario 6-8 $\times 2-3 \mathrm{~mm}$, verde, obovado-oblongo. Estilo $8-9 \mathrm{~mm}$; ramas del estilo 9-10 $\mathrm{mm}$, ascendentes; crestas en el ápice 3, amarillas, las adaxiales 4,5-6,5 mm lanceoladas, la abaxial 1-1,5 mm, triangular. Cápsula 10-12 × 7-8 mm, obovado-oblonga, conteniendo 20-45 semillas. Semillas 1,82,5 mm largo, oblongas u obcónicas, marrón, anguladas, epidermis papilosa o estriada.

Distribución geográfica y hábitat. Cypella charruana crece entre $240-300 \mathrm{~m}$ s.m. en campos húmedos y nacientes a lo largo de la cuenca del río Cuareim entre grietas de rocas basálticas del grupo Arapey, formación Los Catalanes (Bossi \& Navarro, 1988; Bossi \& Navarro, 2007) junto a Cypella herbertii, Rhynchospora tenuis Link, Eryngium pandanifolium Cham. \& Schltdl., Eleocharis montana (Kunth) Roem. \& Schult., Setaria parviflora (Poir.) Kerguélen, Habenaria bractescens Lindl., en los departamentos de Artigas y Rivera, norte del Uruguay y en el sudoeste del Brasil. No se encontró material en herbario proveniente del departamento de Rivera pero existen numerosos registros fotográficos del Parque Municipal Gran Bretaña ubicado al noroeste de la ciudad de Rivera así como de otras localidades del mismo departamento.

Etimología. Se refiere a los "Charrúas", grupos de cazadores y recolectores humanos prehistóricos, que habitaron los pastizales del norte del río de La Plata.

Observaciones. La especie es fácilmente reconocida por sus flores con tépalos externos con unguículo muy angosto, similar en forma y tamaño con los unguículos de los tépalos internos. Además, sus estambres de 16,4-20 mm de longitud y estilo 17-19 mm de longitud son grandes comparados a otras especies presentes en el Uruguay (véase también comentarios bajo C. rivularis).

\section{Material examinado}

URUGUAY. Artigas. Suelo rocoso al margen del arroyo Sepulturas, $30^{\circ} 55^{\prime} 23$ ' S, 56 06' 14" W, 24-I-2015, Berazategui et al. 2762 (MVFA!). Sarandí del Arapey, en campo, 16XI-2014, L. P. Deble, A. S. de Oliveira-Deble \& F. S. Alves 15688 (SI!) 
4. Cypella discolor Ravenna, Wrightia 7 (1): 16. 1981 (sect. Nais). TIPO: Brasil, Rio Grande do Sul, Quaraí, "culta in Bonaria ex bulbis ad Passo da Guarda civit, Rio Grande do Sul, Brasiliae collectis" XII.1967, P. F. Ravenna 507 (Herb. Rav., no localizado). NEOTIPO (Designado por Deble \& Alves (2017b (3) 41: 10) Brasil, Rio Grande do Sul, Quaraí, na localidade do Passo da Guarda, em campo rupestre, [30 18 '21.22”S 55 58'03.58”'W], 16.XII.2010, L. P. Deble \& A. S. Oliveira-Deble 12901 (neotipo: SI!; isoneotipo: CTES!, K). Figs. 4A-E y 2.

Plantas de $15-25 \mathrm{~cm}$, tallo subterráneo de $5-10 \mathrm{~cm}$. Bulbo 20-35 × 20-25 mm, globoso u ovoide, comprimido, prolongado en un collar de 3-7 cm; catáfilos anchamente ovados, suavemente agudos en el ápice, de color marrón oscuro. Hojas basales en la antesis 2 a 4, láminas $15-25 \times 0,2-0,6 \mathrm{~cm}$, linearensiforme. Hoja caulinar 5,5-13,5 × 0,2-0,6 cm, 1/3 basal envolviendo el tallo. Ramas floríferas $13-22 \mathrm{~cm}$ de largo, 2 a 3 ramas. Espatas 2 a 5 por rama, 2,6-3,3 $\times$ 0,3-0,4 cm, herbáceas, verde-amarillentas, pruinosas, 2-valvadas, 1-flora, pedunculadas, pedúnculos $0,4-$ $1,8 \mathrm{~cm}$; valva externa $1,3-1,5 \mathrm{~cm}$, valva interna 2,3-3,1 cm, ambas agudas en el ápice y densamente revestida por puntitos y líneas glandulares; pedicelo 2,3-3 cm, filiforme. Flores 32-40 $\mathrm{mm}$ diámetro, perigonio blanco o blanco-ocráceo, con manchas púrpuras o purpuro-oscuro; concavidad central 15-25 $\mathrm{mm}$ diámetro y 11-15 $\mathrm{mm}$ de profundidad. Tépalos externo 24-27 × 9,5-11 mm, oblongos, pandurados, blanco o blanco-ocráceo, cóncavo en la base; láminas 14,5-17 × 12-14 mm, blancas o blanco-ocráceas, con una banda central purpuro-oscuro, erectas en el tercio basal y patentes en el ápice; unguículo 9-10 $\times$ 2-2,5 $\mathrm{mm}$ de ancho en la base y 7-8 $\mathrm{mm}$ de ancho en el ápice, cuneado, blanco, poco translúcido, con manchas marrón-rojizas. Tépalos internos arqueadorecurvados, $17-18 \times 8-8,5 \mathrm{~mm}$, la mitad proximal inclinada, después curvada arriba, con el tercio distal incurvado y fuertemente reclinado; láminas $8-8,5 \mathrm{~mm}$ ancho, blanca, con una depresión central púrpura o rosada, cubierto por tricomas lipídicos translúcidos, con una parte lateral más alta, blanco-rosada en la mitad proximal, después amarilla, con líneas paralelas purpuro-oscuro y manchas irregulares en toda su extensión; unguículo 8-9,5 × 2-2,2 en la base y 4,5-5,5 mm ancho en el ápice, cuneado, blanco, con líneas y manchas púrpuras. Filamentos 5,2-5,8 mm, delgado, filiformes, levemente inclinados, blancocrema o blanco-rosado, base engrosada, unidos en la base por 0,2-0,5 mm; anteras 5-6 × 1,8-2 mm, oblongas; conectivo 1,2-1,7 $\mathrm{mm}$ de ancho, blancocrema o rosado, tecas oscuras, polen gris-oscuro $\mathrm{u}$ ocráceo. Ovario 4,5-5 × 2-2,5 mm, verde, obovadooblongo. Estilo 4-4,5 mm; ramas del estilo 3-3,5 mm, ascendentes; crestas en el ápice 3, blancas o purpuroclara, las adaxiales 2,5-3,5 $\mathrm{mm}$, lanceoladas o elíptico-lanceoladas, la abaxial 1-1,5 mm, triangular. Cápsula 8-10 × 4-5 mm, obovada, conteniendo $c a$. 60 semillas. Semillas 2,2-2,4 mm largo, oblongas u obcónicas, marrón-oscuro, anguladas, epidermis papilosa o estriada.

Distribución geográfica y hábitat. Cypella discolor crece junto a Discaria americana Gillies \& Hook., Agrostis montevidensis Spreng. ex Nees, Setaria parviflora, Cuphea glutinosa Cham. \& Schltdl., Bulbostylis juncoides (Vahl) Kük. ex Herter, Krapovickasia flavescens (Cav.) Fryxell, Frailea perumbilicata $\mathrm{F}$. Ritter, en campos secos y pedregosos, desarrollados sobre rocas basálticas del grupo Arapey, formación Los Catalanes (Elizalde et al., 1970; Bossi \& Navarro, 1988; Bossi \& Ferrando, 2001) entre los 140-350 m s.m. Reconocida para el suroeste del estado de Río Grande del Sur, Brasil, colecciones recientes en Artigas y Rivera, suman esta especie a la flora del Uruguay, donde parece ser muy escasa.

Etimología. En latín el adjetivo discolor significa "diferente por el color" o de "otro color", una clara referencia a las flores con perigonio blanco o blanco-ocráceo que la especie presenta.

Observaciones. El taxón puede ser fácilmente separado de las demás especies presentes en Uruguay por sus flores con perigonio blanco o blanco-ocráceo, espatas unifloras, cortamente pedunculadas y pruinosas. Por su aspecto general, C. discolor se asemeja a C. ravenniana Deble \& F.S. Alves, la cual habita en campos rocosos del oeste y noroeste de Rio Grande del Sur, Brasil, y nordeste de Corrientes y sur de Misiones, Argentina, puede ser diferenciada por sus flores menores $(32-40 \mathrm{~mm}$ vs $38-55 \mathrm{~mm}$ de diámetro), con perigonio blanco o blanco-ocráceo vs amarillo-gema y estilo menor, con ramas y crestas más cortas. 

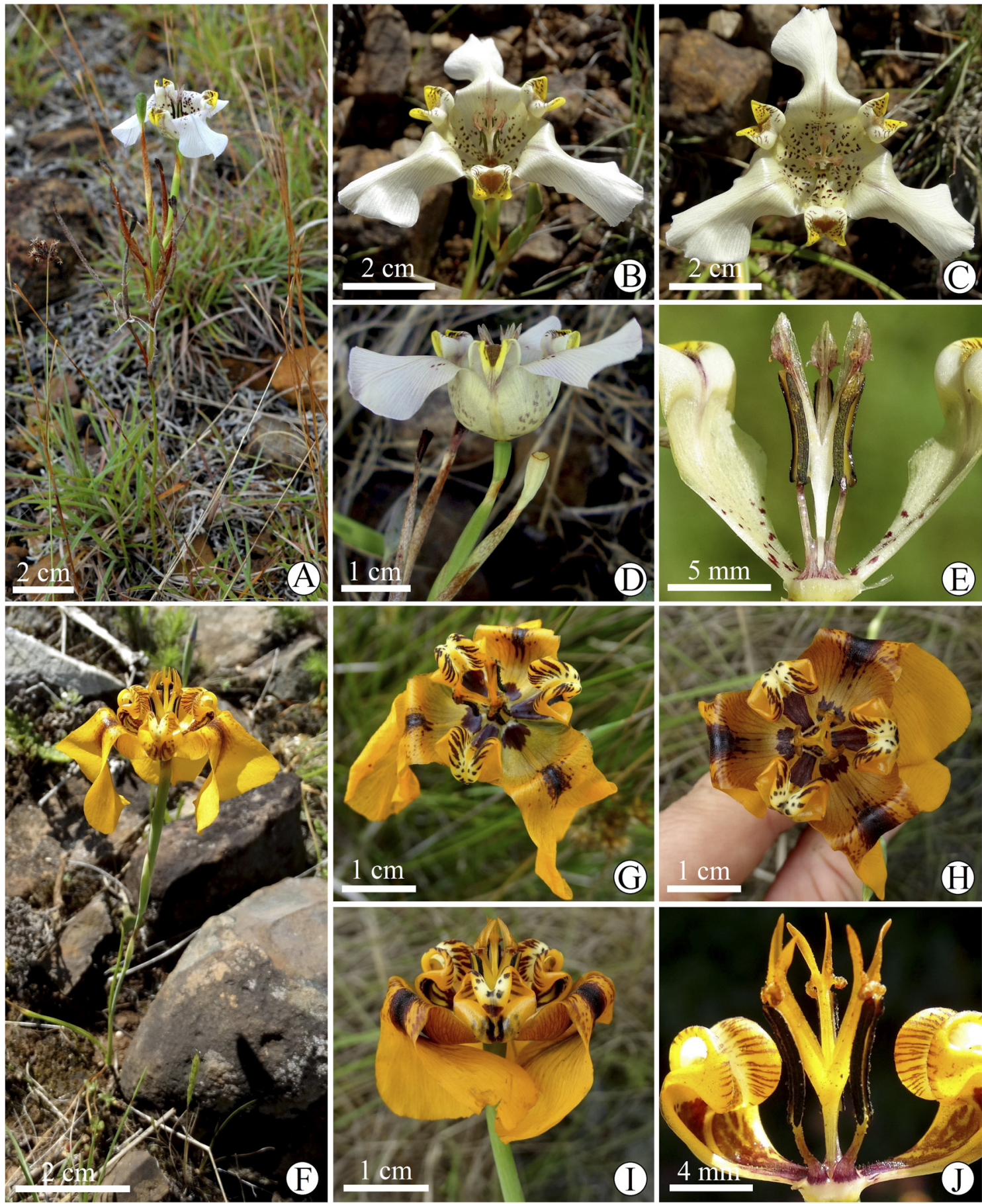

Fig. 4. Cypella discolor (A-E). A, hábito. B, flor, vista oblicua. C, flor vista frontal. D, flor, vista lateral. E, detalle de estambres y estilo, vista lateral. Cypella exilis (F-J). F, hábito. G, flor, vista oblicua. H, flor vista frontal. I, flor, vista lateral. J, detalle de estambres y estilo, vista lateral. A, de González; B-C y E, de Deble \& Moreira 19014; D, de Deble \& Oliveira-Deble 12901; F-I de Deble \& Oliveira-Deble 15649; J, de Deble et al. 12522. Figura en color en la versión en línea http://www.ojs.darwin.edu.ar/index.php/darwiniana/article/view/921/1221 
Cypella discolor fue reconocida como una especie endémica del suroeste del estado de Rio Grande del Sur, en Brasil y evaluada cómo En Peligro (Deble et al., 2012a). En Uruguay esta especie tiene distribución geográfica y poblaciones aún más restringidas que indica que la misma también se encuentra en estado de amenaza.

\section{Material examinado}

URUGUAY. Artigas, Sequeira, flores blancoocráceas, 2-XI-2016, 30³2’47.6”S 56³0’41.0”'W, L. P. Deble \& A. S. de Oliveira 16112 (PACA!); Tres Cruces, $11 \mathrm{~km}$ suroeste de la ciudad de Artigas,4-XI-2017, 30²8'1.41'S 56³6'30.20”O, L. P. Deble \& A. S. de Oliveira 17309 (PACA!). Rivera, Tranqueras, ruta 30, Subida de Pena, 8-XI2019, L.P. Deble \& B.P. Moreira 19014 (PACA!).

5. Cypella exilis Ravenna, Nordic J. Bot. 1: 492. 1981 (sect. Cypella). Polia gracilis Klatt, Linnaea 31 (5): 545. 1862. Cypella gracilis (Klatt) Baker, J. Linn. Soc., Bot. 16: 129. 1877 [non Klatt 1862] [comb. illeg.]. Sphenostigma gracile (Klatt) Benth. \& Hook. f., Gen. Pl. 3 (2): 695. 1883. Phalocallis gracilis (Klatt) Kuntze, Revis. Gen. Pl. 2: 702. 1891. TIPO: Brasil/Uruguay, "Habit. Brasilia meridionalis, Montevideo, leg. Sellow d. 2077, 2079, 2578, d.2578, 3657”. Según Urban (1893: 196) "emenda zum Yaceguay [=Aceguá], über Herval, Serra dos Tapes, nach S. Francisco de Paula [= Pelotas]" II-III.1824, F. Sellow d2077 (lectotipo designado por Deble \& Alves 2017b (3) 41: 13), B[B0366320imagen!]). Figs. 4F-J y 2.

Cypella amplimaculata Chauveau \& L. Eggers, Phytotaxa 174 (1): 29. 2014. TIPO: Brasil, Rio Grande do Sul, Piratini, BR 293, direção Bagé, 140 m" 25.X.2011, A. M. Aita 49 (holotipo: ICN180155!).

Plantas de 10-60 cm de altura, tallo subterráneo de 3-7 cm. Bulbo 9-17 × 8-16 mm, ovoide, prolongado en un collar de 1-3 cm; catáfilos anchamente ovados, agudos en el ápice, de color marrón oscuro. Hojas basales en la antesis 1 a 3, lámina 8-50 × 0,15-0,6 cm, angostamente linear. Hoja caulinar 5,5-16,5 $\times 0,1-0,5 \mathrm{~cm}$, bracteiforme o desarrollada, con hasta $1 / 3$ del total de su largo envolviendo el tallo. Ramas floríferas $9-53 \mathrm{~cm}$ de largo, con 1 a 3 ramas. Espatas 1 a 3 por rama, 4,1$5,8 \times 0,3-0,4 \mathrm{~cm}$, herbáceas, verdes, 2-valvadas, 1-flora, pedunculadas, pedúnculos $2,4-3,8 \mathrm{~cm}$; valva externa $2,1-3,8 \mathrm{~cm}$, valva interna $4-5,8 \mathrm{~cm}$, ambas agudas en el ápice, y terminando en una parte oscura, con líneas paralelas marrón-oscuro; pedicelo 4-5,5 cm, filiforme. Flores $42-60 \mathrm{~mm}$ diámetro, perigonio amarillo-dorado o anaranjado con manchas purpuro-oscuro; concavidad central $15-20 \mathrm{~mm}$ diámetro y 7-9 $\mathrm{mm}$ de profundidad. Tépalos externo 26-40 × 9,5-14 mm, oblongos $\mathrm{u}$ obovado-oblongos, pandurados, amarillo o amarillo-dorado, cóncavo en la base; láminas 16$27 \times 16-25 \mathrm{~mm}$, amarillo-dorada o anaranjada, con una banda longitudinal roja o marrón-rojiza en la mitad basal, revolutas, ápice truncado o redondeado, apiculado; unguículo 9-14 × 2-2,5 mm en la base y 6-7,5 $\mathrm{mm}$ de ancho en el ápice, angostamente cuneado, pálido anaranjado, translúcido, con una mancha marrón-rojiza en la base. Tépalos internos geniculado-recurvados, $10-11 \times 7,5-10 \mathrm{~mm}$ longitud, la mitad proximal inclinada, después curvada arriba, con el tercio distal incurvado y fuertemente reclinado; láminas 7,5-10 mm ancho, amarillo-dorado o anaranjada, con una depresión central blanco-crema, con tricomas lipídicos anaranjados en la base, con una parte lateral más alta, anaranjada, con líneas paralelas marrón-oscuro; unguículo 4,5-5 × 2,5-3 $\mathrm{mm}$ en la base y 5-5,5 $\mathrm{mm}$ ancho en el ápice, cuneado, pálido anaranjado, con líneas y manchas marrón-rojizas. Filamentos 2,5-4,5 mm, obclavados, levemente inclinados, blanco-crema o amarillentos, base engrosada, con manchas o líneas rojizas, unido en la base por 0,2-0,3 mm; anteras 5,5-7 $\times$ 1,3-1,6 mm, angostamente oblongas; conectivo 0,7-1 $\mathrm{mm}$ de ancho, blanco-crema, tecas oscuras, polen gris-oscuro u ocráceo. Ovario $7-10 \times 2,5-3 \mathrm{~mm}$, verde o verde-amarillento, obovado-oblongo. Estilo 6,5-7,5 mm; ramas del estilo 2-2,8 $\mathrm{mm}$, ascendentes; crestas en el ápice 3, anaranjadas, las adaxiales 3-5 mm, lanceoladas, la abaxial 1-2 mm, triangular. Cápsula 11-20 $\times$ 7-8 mm, obovado-oblonga, conteniendo 85-115 semillas. Semillas 1-1,5 mm largo, oblongas $\mathrm{u}$ obcónicas, marrón-claro, anguladas, epidermis papilosa o estriada. 
Distribución geográfica y hábitat. Crece en campos secos y laderas de cerros junto a Parodia herteri (Werderm.) N.P. Taylor, Dyckia sp., Sinningia sellowii (Mart.) Wiehler, Grazielia intermedia (DC.) R.M. King \& H. Rob. y Anemia tomentosa (Savigny) Sw. entre afloramientos de granito en las sierras de Aceguá y suelos de areniscas de la formación Tacuarembó en las quebradas de la Cuchilla Negra (Bossi \& Navarro, 1988), hasta lugares encharcados en pajonales marginales a bosques fluviales junto a Trixis lessingii DC., Paspalum quadrifarium Lam., Scoparia dulcis L., Alstroemeria isabellana Herb., Eryngium pandanifolium y Monnina tristaniana A. St.-Hil. Cypella exilis es una de las especies más comunes del género, el tipo probablemente procede del sur del estado de Río Grande del Sur, Brasil. La especie se extiende en el este y norte del Uruguay desde los 10-350 m s.m., Río Grande del Sur y Santa Catarina en Brasil (comentarios adicionales en Deble, 2017).

Etimología. En latín, el adjetivo exilis significa "tenue" o "pequeño".

Observaciones. Cypella exilis puede ser reconocida por las manchas rojas o purpuras en los tépalos externos y por sus ramas del estilo separadas terminando en crestas largas de color anaranjada. Puede ser confundida con C. fucata, diferenciándose en que esta última especie presenta todos los órganos florales de menor tamaño.

A pesar de presentar una extensa distribución en el norte y este de Uruguay, los ejemplares colectados son muy pocos en los herbarios. Es una de las pocas especies del género con poblaciones numerosas y que no se encuentra en estado de amenaza (Deble, 2017).

\section{Material examinado}

URUGUAY. Cerro Largo, Aceguá, on grasslands and adjacent stony, orange flowers, $4 \mathrm{~cm}$ diameter, adaxial crests up to $4 \mathrm{~mm}, 11$-XII2011, L. P. Deble, A. S. de Oliveira-Deble \& J. B. Rodrigues 12522 (PACA!, SI!). Maldonado, Solís, 24-XI-1917, C. Osten 11643. (MVM 18520!). Rivera, Tranqueras, camino para Cuchilla Negra, 01-XI-2015, L. P. Deble \& A. S. de Oliveira-Deble 15649 (SI!).
6. Cypella fucata Ravenna, Wrightia 7 (1): 18. 1981 (sect. Cypella). TIPO: Brasil, Rio Grande do Sul, Caçapava do Sul, "culta in Bonaria ex bulbis ad pedem collis ubi Gruta do Segredo est pr. Cacapava civit Rio Grande do Sul Brasiliae" XII.1965, P. F. Ravenna 500 (Holotipo: Herb. Rav., no localizado). NEOTIPO (designado por Deble \& Alves 2017b (3) 41: 11): Brasil, Rio Grande do Sul, Caçapava do Sul, "caminho para a gruta do segredo", 23.XII.2009, L. P. Deble \& A. S. de Oliveira-Deble 11032 (neotipo SI!; isoneotipo: CTES!, K). Figs. 5A-E y 2.

Cypella osteniana Beauverd subsp. aurantiaca Roitman \& A. Castillo, Bol. Soc. Argent. Bot.: 337. 2003.). TIPO: Argentina, Corrientes, Depto. Monte Caseros, cercanías de Tres Bocas, 16.IV.2003, Roitman \& Tourn s.n. (holotype BAB no visto).

Cypella aprica Arechav. (in sched.)

Plantas de $12-25 \mathrm{~cm}$, tallo subterráneo de $3-6 \mathrm{~cm}$. Bulbo 10-16 × 10-15 mm, globoso u ovoide, comprimido, prolongado en un collar de $2-4 \mathrm{~cm}$; catáfilos anchamente ovado-lanceolados, agudo o acuminados en el ápice, de color marrón oscuro. Hojas basales en la antesis ausentes o 1 a 2, lámina 10-16 $\times 0,05-0,3 \mathrm{~cm}$, angostamente linear. Hoja caulinar 5-12 $\times 0,1-0,2 \mathrm{~cm}$, ensiforme elíptica, con su parte basal envolviendo el tallo. Ramas floríferas 10-20 cm de largo, con 1 a 2 ramas. Espatas 1 a 2 por rama, 2,8-3,4 $\times 0,2-$ $0,3 \mathrm{~cm}$, herbáceas, verdes, 2-valvadas, 1-flora, pedunculadas, pedúnculos $1,2-3 \mathrm{~cm}$; valva externa 1,4-2,3 cm, valva interna 2,7-3,3 cm, ambas agudas en el ápice y terminando en una parte translúcida, con líneas paralelas naranja-oscuro; pedicelo 3-3,5 cm, filiforme. Flores $25-38 \mathrm{~mm}$ diámetro, perigonio naranja-opaco muy raro amarillo; concavidad central 10-12 mm diámetro y 5-6 mm de profundidad. Tépalos externos 17$25 \times 7-10 \mathrm{~mm}$, obovado-oblongos, pandurados, naranja-opaco, con nervuras ocre-oscuro, cóncavo en la base; láminas 13-17 × 10-12 mm, con venas oscuras, muy reflejas, con abundantes tricomas ocráceos cerca de la base, ápice truncado o redondeado, apiculado; unguículo 7-9 $\times$ 2-2,5 $\mathrm{mm}$ en la base y 7,5-8 $\mathrm{mm}$ de ancho en el ápice, cuneado, naranja-opaco, translúcido. 


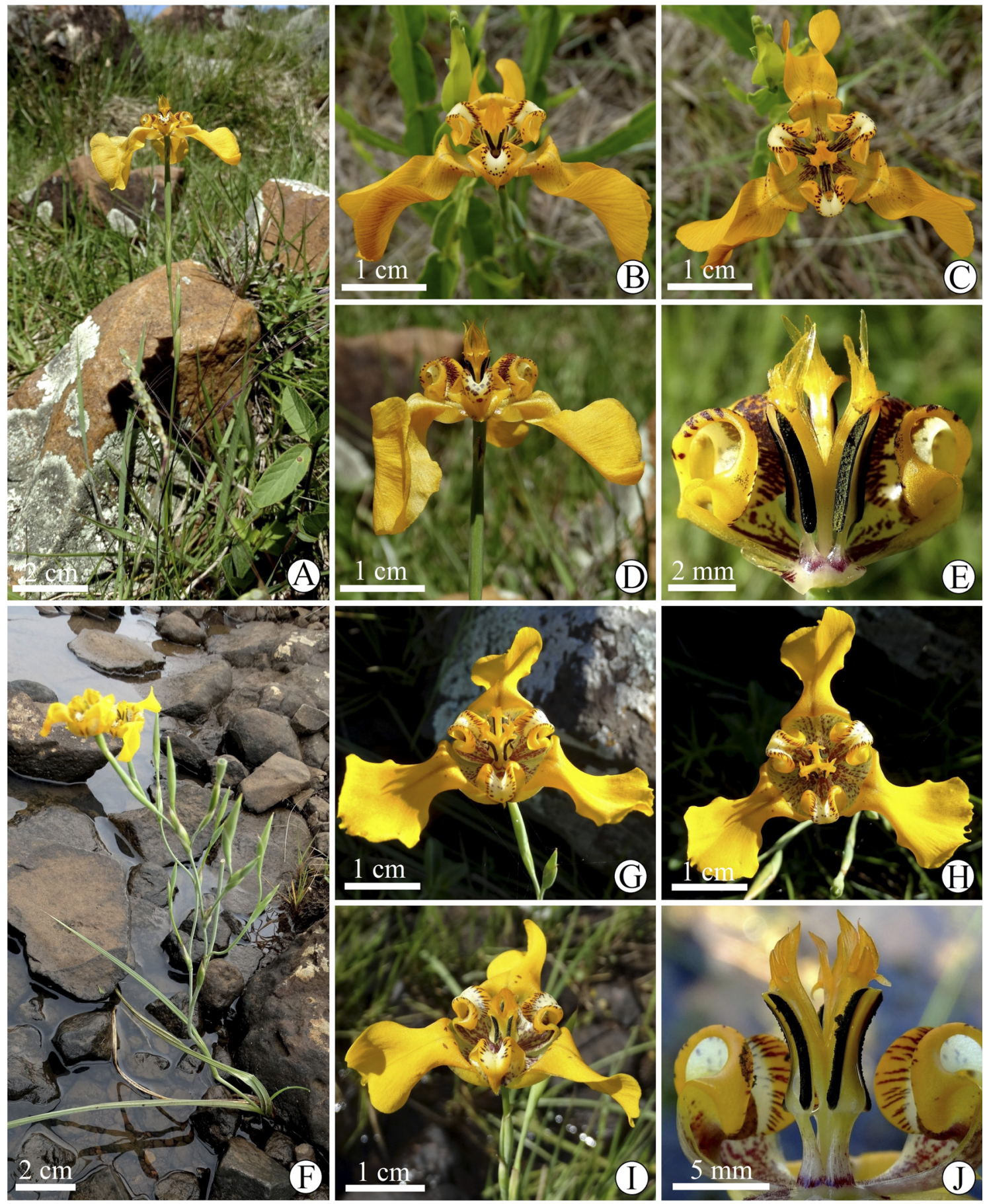

Fig. 5. Cypella fucata (A-E). A, hábito. B, flor, vista oblicua. C, flor vista frontal. D, flor, vista lateral. E, detalle de estambres y estilo, vista lateral. Cypella guttata (F-J). F, hábito. G, flor, vista oblicua. H, flor vista frontal. I, flor, vista lateral. J, detalle de estambres y estilo, vista lateral. A-E de Deble et al. 15700; F, de Deble \& Oliveira 17829; G-H, de Deble \& Oliveira 14228; J, de Deble et al. 14991. Figura en color en la versión en línea http://www.ojs.darwin.edu.ar/ index.php/darwiniana/article/view/921/1221 
Tépalos internos 7-8 $\times 6-7 \mathrm{~mm}$, geniculadorecurvados, la mitad proximal inclinada, después curvada arriba, con el tercio distal incurvado y fuertemente reclinado; láminas 6-7 $\mathrm{mm}$ ancho, naranja, con una depresión central blanco-crema, cubierto por tricomas lipídicos anaranjados cerca de la base, con una parte lateral más alta, con manchas purpuro-oscuro a negras, parte dorsal con una giba anaranjada; unguículo 3,5-4 × 1,8$2,1 \mathrm{~mm}$ en la base y $3,5 \mathrm{~mm}$ ancho en el ápice, cuneado, naranja-opaco, con líneas marrón-rojizas. Filamentos 1,8-2,1 mm, obclavado, declinado, blanco-crema o naranja-pálido, base engrosada, con manchas o líneas rojizas, unido en la base por 0,3-0,4 mm; anteras 3,2-4,5 × 1,8-2,2 mm anchamente oblongas; conectivo 1-1,4 mm de ancho, naranja-pálido, tecas oscuras, polen ocráceo. Ovario 5-6 × 1,8-2 mm, verde o verde-amarillento, obovado. Estilo 7-8 $\mathrm{mm}$, naranja-pálido; ramas del estilo $2-3 \mathrm{~mm}$ de largo ascendentes o casi erectas; crestas en el ápice 3, anaranjadas, las adaxiales 3,8-4,5 $\mathrm{mm}$, lanceoladas, la abaxial 0,5-1 $\mathrm{mm}$, triangular, entera o furcada en el ápice. Cápsula 8-12 $\times$ 4-6 mm, oblonga, conteniendo 25-48 semillas. Semillas $c a .2 \mathrm{~mm}$ largo, oblongas u obcónicas, marrón-rojizas, anguladas, epidermis reticulada.

Distribución y hábitat. Cypella fucata habita en campos secos y rocosos de casi todo el país, siendo más común en los campos sobre suelos arenosos del oeste y en los campos rocosos y cerros del este y sureste creciendo entre los 10-300 m s.m. junto a Nassella neesiana (Trin. \& Rupr.) Barkworth, Chascolytrum subaristatum (Lam.) Desv., Chevreulia sarmentosa (Pers.) S.F. Blake, Herbertia lahuea (Molina) Goldblatt subsp. amoena (Griseb.) Goldblatt, Acanthostyles buniifolius y Lanugothamnus montevidensis (Spreng.) Deble. Su distribución geográfica se extiende a Rio Grande del Sur, Brasil y nordeste de Argentina.

Etimología. La palabra fucata significa "teñido" o "colorido" en latín. Ravenna (1981b) al describir esta especie reconoció su íntima relación con Cypella osteniana, una especie que tiene flores blancas mientras que en C. fucata las flores son naranja-opaco.
Observaciones. Cypella fucata puede ser fácilmente reconocida por sus flores con perigonio naranja-opaco y reducido tamaño de las partes florales. Además, las ramas del estilo se presentan adheridas en la mitad basal y las crestas son largas y muy próximas. Una de las especies más comunes del género con poblaciones muy abundantes y por eso no se encuentra en estado amenazado. Al igual que otras especies del género se encuentra muy poco representada en las colecciones de herbarios nacionales.

\section{Material examinado}

URUGUAY. Cerro largo, 23-XII-1961, D. Legrand, 4794 (MVM 18514!). Paso de Tía Lucia, flor amarillo claro, 11-XI-1965, s. leg. $n$. 2537 (MVFA!). Durazno, Paso Ramírez, costa de rio Negro, con bulbo, 24-II-1994. R. Brescia et al. s.n. (MVFA 23002!). Florida, ruta 7, após a cidade de Reboledo, aprox. km 173,5, 33³9'27,7S $55^{\circ} 22^{\prime} 32,4^{\prime \prime} \mathrm{W}$, campo baixo pastejado, com afloramentos rochosos", $200 \mathrm{~m}, 12-\mathrm{XI}-2013, \mathrm{~L}$. Eggers et al. 860 (ICN 180008!). Maldonado, Cerro del Toro, s.d., C. Osten, 5706 (MVM 18.531!). Montevideo, I-1868,M.Fruchards.n.(P02065117!); 18-X-1876, M. Fruchard s.n. (P02167418!); 18-X1876, M. Fruchard s.n. (P02167418!) 30-XI-1876, M. Fruchard s.n. (P02167414!); Carrasco, 12-III1871 M. Fruchard s.n. (P02165272!); Cerro, 17-I1875, M. Fruchard s.n. (P02065115!); s.l., s.d., C. Osten 5197 (MVM 18457!). Cerro de Montevideo, V-1900, J. Arechavaleta s.n. (MVM 18511!).; 1-IV1947, D. Legrand, 2622 (MVM 18517!). Rivera. Cerro Aurora, 10/12-II-1961, Arrillaga et al. 1225 (MVFA!). Salto, en el camino a las termas del Arapey, 20-X-1961, Millot 535 (MVFA!).

7. Cypella guttata Deble \& F.S. Alves, Phytotaxa 236: 105. 2015. TIPO: Uruguay, Artigas, Sarandi de Arapey, "cerca de $11 \mathrm{~km}$ nordeste da vila de Sarandí de Arapey, $30^{\circ}$ 57' 45.22”S, 56 06'09.75'O, 22.X.2014, L.P. Deble, A.S. de Oliveira \& F.S. Alves 14991 (isotipo SI!, ICN!). Figs. 5F-J y 2.

Plantas de 20-60 cm de altura, tallo subterráneo de 8-20 cm. Bulbo $25-40 \times 25-35 \mathrm{~mm}$, globoso u ovoide, comprimido, prolongado en un collar de 8-13 cm; catáfilos anchamente ovado, agudo o 
acuminados en el ápice, de color marrón oscuro. Hojas basales en la antesis 2 a 7, lámina 18-35 × 0,5-1,2 cm, lanceolado-elíptica. Hoja caulinar 12,5-18 $\times 0,5-1 \mathrm{~cm}$, ensiforme elíptica, con su parte basal envolviendo el tallo. Ramas floríferas $12-45 \mathrm{~cm}$ de largo, con 2 a 6 ramas. Espatas 2 a 8 por ramas, 2,7-3,4 ×0,3-0,4 cm, herbáceas, verdes, 2-valvadas, 1-flora, pedunculadas, pedúnculos 1,6$4,5 \mathrm{~cm}$; valva externa $1,4-1,9 \mathrm{~cm}$, valva interna 2,7-3,4 cm, ambas agudas en el ápice y terminando en una parte translúcida, con líneas paralelas marrón-oscuro; pedicelo 2,5-3,5 cm, filiforme. Flores $33-40 \mathrm{~mm}$ diámetro, perigonio amarillodorado, brillantes, con manchas marrón-rojizas; concavidad central 12-15 mm diámetro y 6-8 mm de profundidad. Tépalos externo 28-33 × 8-10 mm, oblongos $\mathrm{u}$ obovado-oblongos, pandurados, amarillo o amarillo-dorado, cóncavo en la base; láminas 20-25 × 10-12 mm, amarilla o amarillodorada, con escasos puntitos marrón-rojizos en la base, suavemente patentes y torcidas, ápice truncado o redondeado, apiculado; unguículo 9$10 \times 2,5-3 \mathrm{~mm}$ de ancho en la base y 8,5-9,5 $\mathrm{mm}$ de ancho en el ápice, anchamente cuneado, pálido amarillento o dorado, translúcido, con puntitos rojos o marrón-rojizos densos. Tépalos internos 8-9 × 7-8 mm, geniculado-recurvados, la mitad proximal inclinada, después curvada arriba, con el tercio distal incurvado y fuertemente reclinado; láminas 7-8 mm de ancho, amarillo-doradas, con una depresión central blanco-crema, cubierto por tricomas lipídicos anaranjados cerca de la base, con una parte lateral más alta, con manchas y líneas paralelas marrón-rojizas; unguículo 4,5-5,5 $\times$ 2-2,2 $\mathrm{mm}$ de ancho en la base y 4-5 $\mathrm{mm}$ ancho en el ápice, cuneado, pálido amarillento, translúcido, con numerosas líneas y manchas marrón-rojizas. Filamentos 4.5-5 mm de largo, en forma de cinta, levemente inclinados, blanco-crema o amarillento, base engrosada, con manchas o líneas rojizas, unidos en la base por $0,5-0,8 \mathrm{~mm}$; anteras 5,5-6 × 2,2$2,5 \mathrm{~mm}$, anchamente oblongas; conectivo 2-2,2 $\mathrm{mm}$ de ancho, blanco-crema o amarillento, tecas oscuras, polen gris-oscuro u ocráceo. Ovario 5-6 × 1,7$2,1 \mathrm{~mm}$, verde o verde-amarillento, obovado. Estilo 7,5-8,5 mm; ramas del estilo 4,5-5 $\mathrm{mm}$ de largo, ascendentes; crestas en el ápice 3, anaranjadas, las adaxiales 3-3,5 mm, lanceoladas, la abaxial 1-1,4 mm, triangular, entera o furcada en el ápice.
Cápsula 14-20 × 6,5-10 mm, oblonga, conteniendo 73-95 semillas. Semillas 2,8-3,5 mm oblongas u obcónicas, marrón-rojizas, largo, anguladas, epidermis con estrías y algunas papilas.

Distribución geográfica y hábitat. Cypella guttata crece junto a Paspalum indecorum Mez, Croton subpannosus Müll. Arg. ex Griseb., Ruellia hypericoides (Nees) Lindau, Myrcianthes cisplatensis (Cambess.) O. Berg y Lithraea molleoides (Vell.) Engl. cerca de arroyos y pequeñas corrientes, entre grietas de rocas y campos pedregosos de origen basáltico correspondientes al grupo Arapey, formaciones Los Catalanes y Curtina (Bossi \& Navarro, 1988) entre los 140-320 m s.m. en las cuencas de los ríos Cuareim y Tacuarembó, en Uruguay así como también en áreas adyacentes en Brasil, donde es simpátrica con C. charruana y C. rivularis, otras especies restrictas a estos lugares.

Etimología. Del latín guttatus que significa manchado y se refiere a los puntitos rojos en la concavidad central, que a veces se expanden hasta la base de las láminas.

Observaciones. Cypella guttata es parecida a C. herbertii subsp. brevicristata, de la cual puede separarse por sus flores naranjas vs amarillas, estambres con filamentos en forma de cinta y separados vs filamentos cónicos muy aproximados y anteras con conectivo de 2-2,2 $\mathrm{mm}$ de ancho vs 3-3,6 mm de ancho. Cypella guttata presenta un patrón regular en la concavidad central del perianto conformado por pequeñas manchas en forma de puntitos rojos.

Por su reducida distribución geográfica, hábitat muy específico, desarrollo cerca de arroyos y pequeñas corrientes en campos rocosos de la cuenca de los ríos Cuareim y Tacuarembó fue considerada Críticamente Amenazada (Deble et al., 2015a).

\section{Material examinado}

URUGUAY. Artigas: Baltasar Brum, en pastizal húmedos, 12-X-2017, L.P. Deble \& A.S. de Oliveira 17829 (PACA!). Rivera: "ruta UY 30, $31^{\circ} 05^{\prime} 23,15^{\prime}$ ' S y $55^{\circ} 58$ ' 59,54 " W, cercanías de Masoller", 10-X-2012, L.P. Deble \& A.S. de Oliveira 14228 (PACA!). 


\section{Cypella herbertii}

8.1. Cypella herbertii (Herbert) Herbert subsp. herbertii, Bot. Mag. 53: pl. 2637. 1826. Tigridia herbertii Herbert, Bot. Mag. 52: pl. 2599. 1825. Moraea herbertii (Herbert) Lindley, Bot. Reg. 11: pl. 949. 1825 [1826]. Phalocallis herbertii (Herbert) Kuntze, Rev. Gen. Pl. 2: 702. 1891. TIPO: Argentina, Buenos Aires, sin datos adicionales (holotipo Botanical Magazine 52, Plancha 2599). Lectotipo (designado por Deble \& Alves, 2020: 15): Original plate 2599, Botanical Magazine 25. 1825. EPITIPO (designado por Eggers et al., 2019: 759): Argentina. Buenos Aires, s.d., J. Tweedie 765 (K [K000523855 imagen!]). Figs. 6A-E y 7.

Cypella bonariensis (Tenore) Niederl., Bol. Mens. Mus. Prod. Argent. 3 (31): 332. 1890. Polia bonariensis Tenore, Cat. Orto Bot. Napoli: 92. 1845.

Cypella ramosa (Klatt) Klatt, Abh. Naturf. Ges. Halle 15: 364. 1882. Polia ramosa Klatt, Linnaea 31: 544. 1862. Cypella ramosa (Klatt) Beauverd, Bull. Soc. Bot. Genève ser. 2, 14: 167, 1923. [nom. superfl.]. TIPO: Uruguay, "Montevideo, leg. Sellow no. 765" F. Sellow 765 (holotipo: K [K000523858] imagen!).

Plantas de 30-100 cm de altura, tallos subterráneos de 4-20 cm. Bulbo 12-25 × 10-16 mm, globoso u ovoide, comprimido, prolongado en un collar de 2-8 cm; catáfilos ovado u ovadoelípticos, agudo o acuminados en el ápice, de color marrón oscuro o marrón. Hojas basales en la antesis 1 a 4, lámina 25-75 × 0,4-1,4 cm, lanceolado-elíptica. Hoja caulinar 15-35 $\times 0,5$ $1,5 \mathrm{~cm}$, ensiforme elíptica, con su parte basal envolviendo el tallo. Ramas floríferas $25-85 \mathrm{~cm}$ de largo, con 2 a 8 ramas. Espatas 2 a 8 por rama, 3-5,2 $\times 0,3-0,4 \mathrm{~cm}$, herbáceas, verdes, 2-valvadas, 1-flora, pedunculadas, pedúnculos $1,3-5 \mathrm{~cm}$; valva externa 1,8-2,9 cm, valva interna 2,9-5,1 cm, la más externa redondeada y translúcida en el ápice, la interna aguda en el ápice y terminando en una parte translúcida, con líneas paralelas marrón-oscuro; pedicelo $3,5-5,5 \mathrm{~cm}$, filiforme. Flores 45-55 mm diámetro, perigonio amarillo- dorado, anaranjado o anaranjado-ocráceo, con una línea marrón-rojiza; concavidad central 9-12 mm diámetro y 5-8 $\mathrm{mm}$ de profundidad. Tépalos externo 35-45 × 7-10 mm, oblongos u obovado-oblongos, pandurados, amarillodorados, anaranjados o anaranjado-ocráceos, cóncavo en la base; láminas $26-35 \times 10-12 \mathrm{~mm}$, con una línea marrón-rojiza central que se extiende desde la base hasta la parte mediana, suavemente patentes y torcidas, ápice truncado o redondeado, apiculado; unguículo 8-10 × 2,5-3 $\mathrm{mm}$ de ancho en la base y 8,5-9,5 $\mathrm{mm}$ de ancho en el ápice, anchamente cuneado, pálido amarillento o dorado, translúcido, con una línea marrón-oscura central. Tépalos internos geniculado-recurvados, 9-10 $\times$ 8-9 mm, la mitad proximal inclinada, después curvada arriba, con el tercio distal incurvado y fuertemente reclinado; láminas $8-9 \mathrm{~mm}$ ancho, amarillo-dorado, con una depresión central blanco-crema, cubierto por tricomas lipídicos anaranjados cerca de la base, con una parte lateral más alta, con manchas y líneas paralelas marrón-rojizas; unguículo 4,5-5,5 × 2-2,2 mm de ancho en la base y 4-5 $\mathrm{mm}$ ancho en el ápice, cuneado, pálido amarillento, translúcido, con manchas marrón-rojizas. Filamentos 2,5-3,5 mm, cónico, levemente inclinados, purpuro o marrónrojizo, base engrosada, con manchas o líneas rojizas, unido en la base por 0,5-2 $\mathrm{mm}$; anteras 6-7,5 $\times$ 2,5-3 $\mathrm{mm}$, anchamente oblongas; conectivo 2,4-2,6 $\mathrm{mm}$ de ancho, blanco-crema, con manchas rojizas, tecas oscuras, polen grisoscuro u ocráceo. Ovario 6-8 × 1,5-2 mm, verde o verde-amarillento, obovado. Estilo 9,5-11 mm de largo, blanquecino en la base y purpuro-oscuro en el ápice; ramas del estilo 2,5-4,5 mm de largo, ascendentes o casi erectas; crestas en el ápice 3, purpuras, las adaxiales $2-4,5 \mathrm{~mm}$, lanceoladas, la abaxial 1-1,2 $\mathrm{mm}$, triangular, entera o furcada en el ápice. Cápsula 12-25 × 4-6 mm oblonga, conteniendo 85-134 semillas. Semillas 2-2,5 mm largo, oblongas u obcónicas, marrón-rojizas, anguladas, epidermis con estrías y reticulada.

Distribución geográfica y hábitat. Cypella herbertii subsp. herbertii es la especie con mayor distribución en el género, habita en el este y nordeste de la Argentina, todo Uruguay y sur de Brasil, principalmente en el sur de Rio Grande del Sur. 

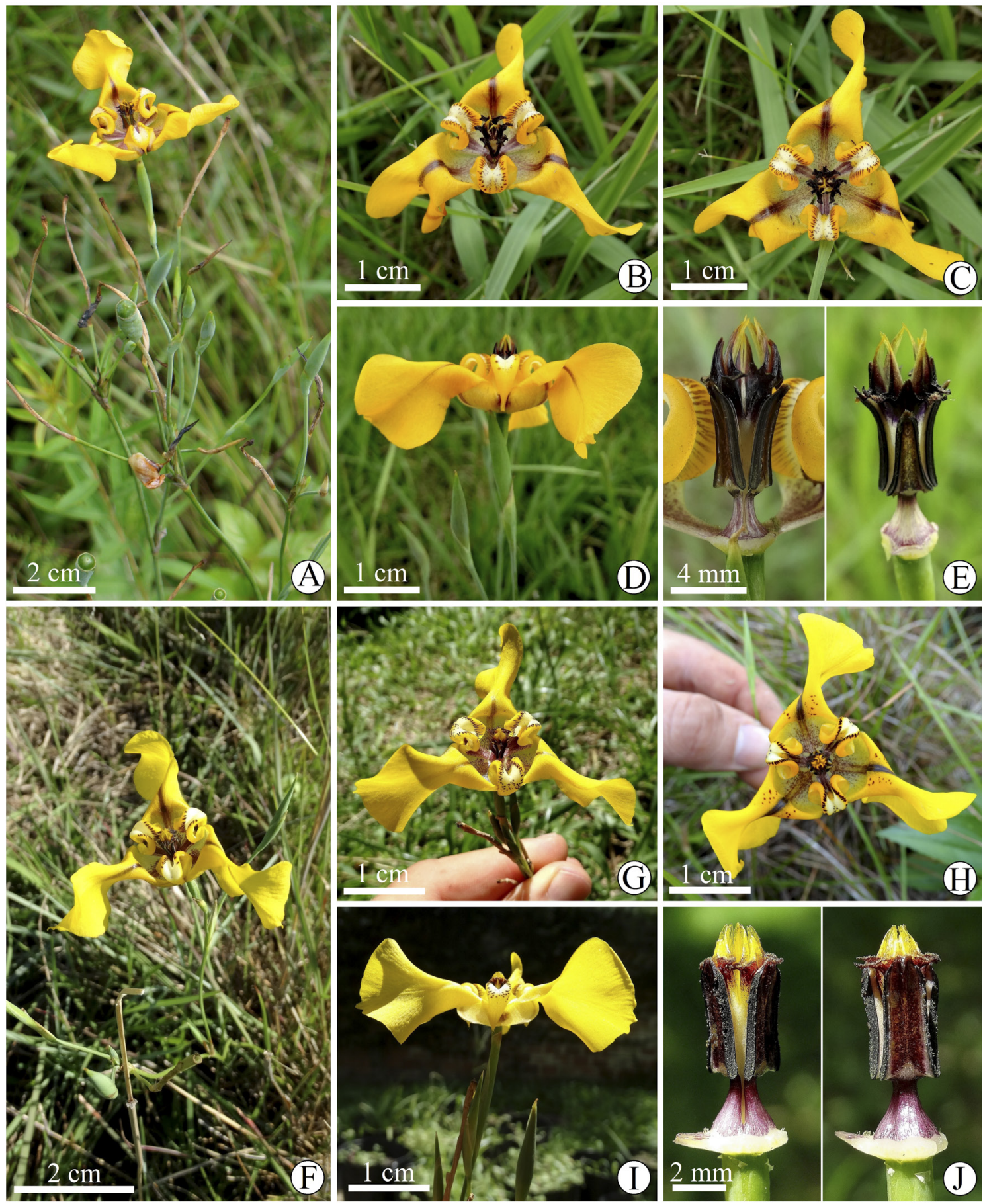

Fig. 6. Cypella herbertii subsp. herbertii (A-E). A, ramo en flor. B, flor, vista oblicua. C, flor vista frontal. D, flor, vista lateral. E, detalle de estambres y estilo, vista lateral y frontal. Cypella herbertii subsp. reflexa (F-J). F, ramo en flor. G, flor, vista oblicua. H, flor vista frontal. I, flor, vista lateral. J, detalle de estambres y estilo, vista lateral y frontal. A-E de Deble \& Moreira 19044; F-J, de Deble et al. 15306. Figura en color en la versión en línea http://www.ojs.darwin.edu.ar/ index.php/darwiniana/article/view/921/1221 


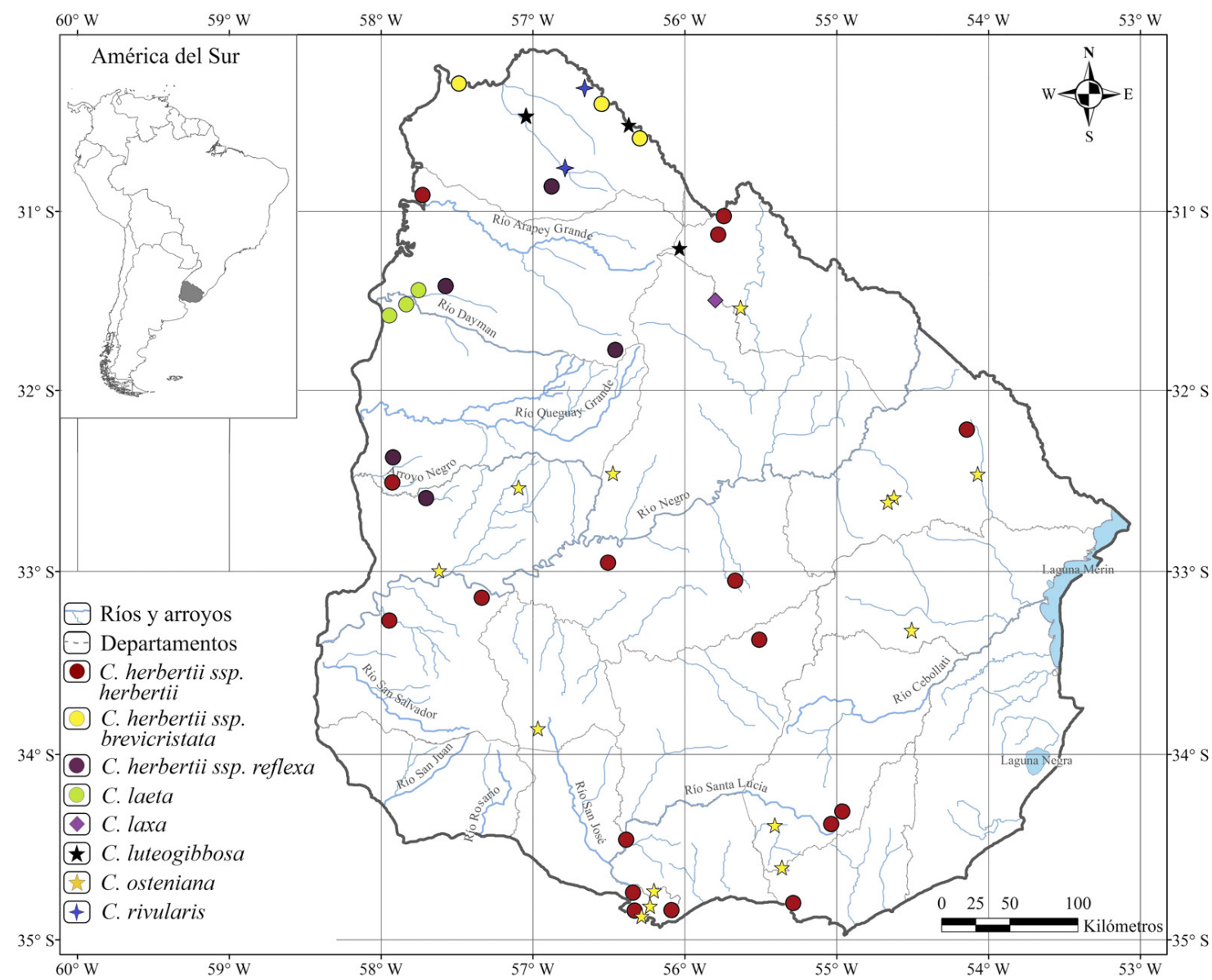

Fig. 7. Mapa de distribución de Cypella herbertii subsp. brevicristata, C. herbertii subsp. herbertii, $C$. herbertii subsp. reflexa, C. laeta, C. laxa, C. luteogibbosa, C. osteniana y C. rivularis. Figura en color en la versión en línea http://www.ojs.darwin.edu.ar/index.php/darwiniana/article/view/921/1221

$\mathrm{Su}$ límite norte de distribución es en la municipalidad de Colombo, nordeste del estado de Paraná. En Uruguay crece entre los 5-300 m s.m. al margen de cursos de agua y bajos inundables junto a Symphyotrichum squamatum (Spreng.) G.L. Nesom, Leersia hexandra Sw., Eryngium pandanifolium, Vicia graminea Sm., Marsilea ancylopoda A. Braun y Eleocharis viridans Kük. ex Osten.

Etimología. William Herbert dedicó su nueva especie al Reverendo George Herbert.

Observaciones. Cypella herbertii subsp. herbertii puede ser reconocida por sus estambres con filamentos en forma cónica, anteras con conectivo ancho, generalmente de color purpura y estilo blanquecino en la base y purpuro-oscuro en el ápice, mientras la línea estigmática es de color purpuro-oscuro. La subespecie presenta amplia distribución y es muy común por lo tanto no se encuentra en estado de amenaza.

\section{Material Examinado}

URUGUAY. Canelones, Santa Lucía, "bois Sta Lucia", 25-I-1874, M. Fruchard (P02065116!; P02065117!). Cerro Largo, Melo, ruta 8, entre

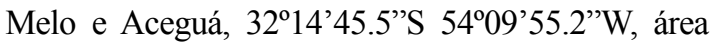
úmida, 13-XI-2013, L. Eggers et al. 862 (ICN 180025!). Durazno, Arroyo Chileno Grande, flor amarillo-anaranjado, 21-III-1971, Ziliani et al. 10605 (MVFA!); Molles, IV-1930, A. Lombardo 1324 (MVJB). Florida, ruta 6, km 198, campo bajo y 
arenoso, 25-III-1994, Bayce et al. (MVFA 24678!). Lavalleja, Penitente, campis graminosis humidis, 17/22-III-1924, C. Osten 17163 (MVM 18526!). Villa Serrana, Mesón de las Cañas, 27-XI-1961, Millot 789 (MVFA!). Maldonado, Pan de Azúcar, 19-XII-1931, C. Osten, 22354 (MVM 18522!). Montevideo, XI1767, P. Commerson s.n. (P02167450!); 20-I-1856, M. Courbon 962 (P02167453!); III-1870, G. Gibert 499 (MVM 18512); Cerro, flor de color amarillento, 1-IV-1947, D. Legrand 2.618 (MVM 18516!); Cantera de Carrasco, 19-II-1951, D. Legrand 3687 (MVM 18.515!); campos, flor amarillada, XI-1877, J. Arechavaleta 26 (MVM 18523!). Paysandú, Arroyo Rabón, 2-III-1969, Del Puerto \& E. Marchesi s.n. (MVFA!). Rivera, Tranqueras, sobre arenisca húmeda, 18-XII-1945, D. Legrand 4.101 (MVM 18518!); Cerro Aurora, flor amarilla, 10/12II-1961, B. P. R. Arrillaga et al.1233 (MVFA!). San José, 5-XII-1925, A. Lombardo 2038 (MVJB!); barra del río Santa Lucía, IV-1926, A. Lombardo 4913 (MVJB). Salto, área a inundar por represa Salto Grande, entre arroyo Espinillar y río Arapey, 2226-XI-1977, Del Puerto 14646 (MVFA!). Soriano, Mercedes, 7-XI-1894, C. Osten 3178 (MVM 18.528!); Vera, 30-X-1898, M. Berro 110 (MVFA!).

Cypella herbertii es un taxón de sistemática muy compleja, proponiendo Ravenna la segregación a nivel de subespecies y formas (ver Ravenna, 1965; 1981b). Cypella herbertii es variable en tamaño, observándose poblaciones con individuos de $30 \mathrm{~cm}$ hasta $170 \mathrm{~cm}$ de altura en la subespecie wolffhuegelii (Hauman-Merck) Ravenna. Además, presenta variaciones en el desarrollo de las ramas del estilo, crestas, ancho de los filamentos y conectivo. Para el Uruguay, Deble \& Alves (2017a) reconocen la presencia de $C$. herbertii subsp. herbertii y $C$. herbertii subsp. brevicristata Ravenna, pudiendo distinguirse ambos taxones por el hábitat donde crecen y tamaño de las partes florales. En este estudio se agrega también $C$. herbertii subsp. reflexa con hábito más esbelto y tépalos externos retorcido-reflejos.

8.2. Cypella herbertii (Herbert) Herbert subsp. brevicristata Ravenna, Not. Bol. Soc. Argent. Botánica 10 (4): 312. 1965. TIPO: Uruguay, Artigas, "Culta in Bonaria ex bulbis collectis in septentrione Uruguay in proximus locibus urbi Artigas, in campis inter fruticis" P.F. Ravenna 01, XI.1959 (holotypus: Herb. Rav. not localized). NEOTIPO (Designado por Deble \& Alves 2017a: 21): Uruguay, Artigas, arroyo Pintadito, $30^{\circ} 25^{\prime} 58.91^{\prime \prime S}$ and $56^{\circ} 26^{\prime} 45.02^{\prime \prime} \mathrm{W}$, 6.XII.2015, L.P. Deble \& F.S. Alves 15996 (neotipo: SI!). Figs. 8A-E y 7.

Plantas de 30-70 $\mathrm{cm}$ de altura, tallos subterráneos de 4-11 cm. Bulbos 15-22 × 14$16 \mathrm{~mm}$, globosos u ovoides, comprimidos, prolongado en un collar de $2-4 \mathrm{~cm}$; catáfilos anchamente ovado-elípticos, agudos o acuminados en el ápice, de color marrón. Hojas basales en la antesis ausentes o hasta 4 , lámina $15-45 \times 0,4-1,5 \mathrm{~cm}$, lanceoladas. Hoja caulinar $8,5-20 \times 0,8-1,5 \mathrm{~cm}$, ensiforme elíptica, con su parte basal envolviendo el tallo. Ramas floríferas $25-65 \mathrm{~cm}$ de largo, con 3 a 8 ramas. Espatas 2 a 6 por rama, 1,8-3,4 $\times 0,3-0,4 \mathrm{~cm}$, herbáceas, verdes, 2-valvadas, 1-flora, pedunculadas, pedúnculos 1-3,5 cm; valva externa 1,6-1,9 cm, valva interna 2,2-3,4 cm, ambas obtusas en el ápice y terminando en una parte translúcida, con líneas paralelas marrón-oscuro; pedicelo 2,5$3,5 \mathrm{~cm}$ filiforme. Flores $34-40 \mathrm{~mm}$ diámetro, perigonio amarillo, brillantes, con una línea central marrón; concavidad central 10-12 mm diámetro y 6-8 $\mathrm{mm}$ de profundidad. Tépalos externos 21-29 × 8-9 mm, obovado, pandurados, amarillo, cóncavo en la base; láminas 15-20 × 10-12 mm, con una línea marrón-oscura central que se extiende desde la base hasta la parte media, suavemente patentes, ápice truncado o redondeado, apiculado; unguículo 8-9 $\times$ 2,5-3 $\mathrm{mm}$ de ancho en la base y 8-9,5 $\mathrm{mm}$ de ancho en el ápice, cuneado, pálido amarillento, translúcido. Tépalos internos 9-10 × 8-9 mm, geniculado-recurvados, longitud, la mitad proximal inclinada, después curvada arriba, con el tercio distal incurvado y fuertemente reclinado; 8-9 × 8-9 mm ancho, amarillas, con una depresión central blanco-crema, cubierto por tricomas lipídicos anaranjados cerca de la base, con una parte lateral más alta, con manchas y líneas paralelas marrón-rojizas; unguículo 5-6 $\times$ 2-2,1 $\mathrm{mm}$ de ancho en la base y 4-4,5 $\mathrm{mm}$ ancho en el ápice, cuneado, pálido amarillento, translúcido, con líneas paralelas marrón-rojizas. 

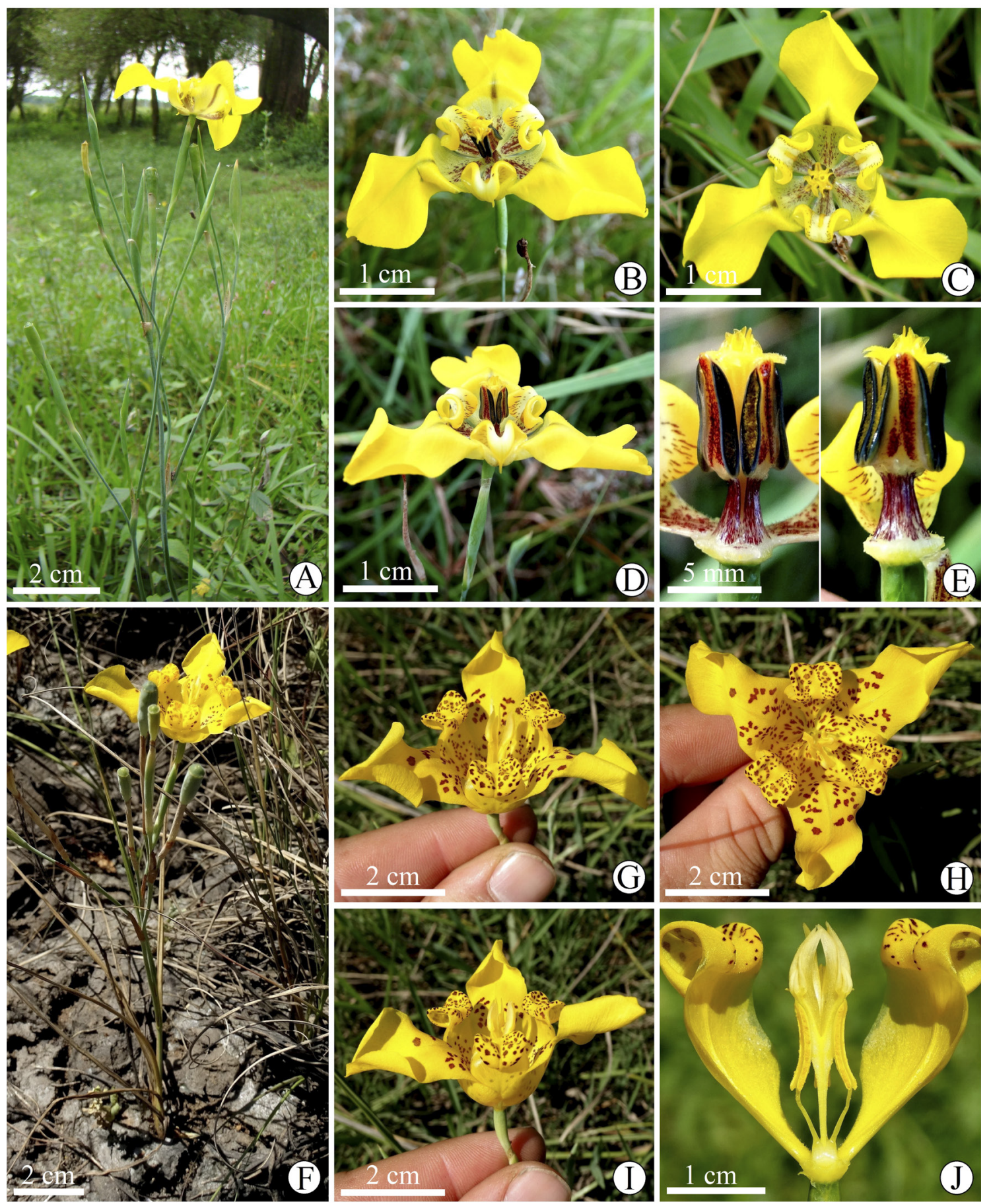

Fig. 8. Cypella herbertii subsp. brevicristata (A-E). A, ramo en flor. B, flor, vista oblicua. C, flor vista frontal. D, flor, vista lateral. E, detalle de estambres y estilo, vista lateral y frontal. Cypella rivularis (F-J). F, habito. G, flor, vista oblicua. H, flor, vista frontal. I, flor, vista lateral. J, detalle de estambres y estilo, vista lateral. A-E, de Deble \& Alves 15996; F-J, de Deble et al. 16504. Figura en color en la versión en línea http://www.ojs.darwin.edu.ar/index.php/ darwiniana/article/view/921/1221 
Filamento 5-5,5 mm, cónico, levemente inclinados, purpuro o marrón-rojizo, base engrosada, con manchas o líneas rojizas, unido en la base por 1-2,5 mm; anteras 6-7 × 3,3-3,8 mm, anchamente oblongas; conectivo $3-3,6 \mathrm{~mm}$ de ancho, blancocrema, con manchas rojizas, tecas oscuras, polen gris-oscuro u ocráceo. Ovario 6-8 $\times 1,5-2 \mathrm{~mm}$, verde o verde-amarillento, obovado. Estilo 8,5$9,5 \mathrm{~mm}$ de largo, blanquecino en la base y amarillo en el ápice; ramas del estilo 2,3-2,8 mm de largo, ascendentes o casi erectas; crestas en el ápice 3, amarillentas, las adaxiales $0,5-0,8 \mathrm{~mm}$, triangulares, la abaxial $0,5 \mathrm{~mm}$, triangular, furcada en el ápice. Cápsula 14-18 × 3,5-5 mm, obovado-oblonga, conteniendo $c a$. 60 semillas. Semillas 2-2,5 mm de largo, oblongas u obcónicas, marrón-rojizas, anguladas, epidermis con estrías y reticulada.

Distribución geográfica y hábitat. Es una subespecie hasta ahora colectada únicamente en la cuenca del río Cuareim entre los 50-100 m s.m., donde crece sobre suelos aluviales y fisuras de rocas basálticas del grupo Arapey, formación Tomás Gomensoro (Bossi \& Navarro, 1988; Bossi \& Schipilov, 2007) junto a Cuphea racemosa (L. f.) Spreng., Oxalis paludosa A. St.-Hil., Eriochloa punctata (L.) Desv. ex Ham, Discolobium psoraleaefolium Benth., Paspalum notatum y Ruellia morongii Britton generalmente en márgenes de bosques de galería en las cercanías de las ciudades de Artigas y Quaraí, en Brasil, extendiéndose hasta la desembocadura con el río Uruguay, cerca de Bella Unión.

Etimología. Del latín brevis (= breve, corto) y cristatus (= cresta), en referencia a las crestas de las ramas del estilo que son muy cortas en comparación con las crestas de $C$. herbertii subsp. herbertii.

Observaciones. Cypella herbertii subsp. brevicristata puede ser diferenciada de Cypella herbertii subsp. herbertii por sus hojas más flácidas, flores de 34-40 $\mathrm{mm}$ de diámetro vs flores de 45-55 $\mathrm{mm}$ en la subsp. herbertii, tépalos externos de 21-29 × 8-9 $\mathrm{mm}$ vs 35-45 × 7-10 $\mathrm{mm}$, anteras con conectivo de 3-3,6 $\mathrm{mm}$ de ancho vs 2,4-2,6 $\mathrm{mm}$, ramas del estilo con crestas muy breves de 0,5 $0,8 \mathrm{~mm}$ vs ramas del estilo con crestas desarrolladas de $1-4,5 \mathrm{~mm}$ y frutos de $14-18 \times 3,5-5 \mathrm{~mm}$ conteniendo $c a$. 60 semillas vs frutos de 12-25 $\times$ 4-6 mm conteniendo 85-134 semillas. Deble \& Alves (2017a) consideraron dicha subespecie cómo en peligro de extinción debido a la pequeña extensión de su ocurrencia, área reducida de ocupación, hábitat específico y disminución en la calidad del hábitat.

\section{Material examinado}

URUGUAY. Artigas, Artigas, orillas de bosque ribereño, abierto, arroyo Catalán Grande, Paso Urumbeba, a $2 \mathrm{~km}$ del rio Cuareim, Colonia Pintado, flores amarillas, 26-X-2002, C. Brussa, et al. s.n. (MVFA 29862!). Pai Paso, 18-II-2004, C. Brussa et al. s.n. (MVJB 21546!). BRASIL. Rio Grande do Sul, Barra do Quaraí, marco da tríplice fronteira, em clareira em meio a floresta de galeria, 30¹1'05.69'S 57'35'58.16" 3-XII-2011, F. S. Alves \& J.N.C. Marchiori 842 (SI!).

8.3. Cypella herbertii (Herbert) Herbert subsp. reflexa Ravenna, Wrigthia 7(1): 22. 1981. TIPO: ARGENTINA, Entre Rios, Paraná, “prope Paraná, ad viam Maria Grande prov. Entre Rios Argentinae" XII.1969, P. F. Ravenna 1042 (holotipo: Herb. Rav. no visto). Figs. 6F-J y 7.

Plantas de $35-80 \mathrm{~cm}$ de altura, tallos subterráneos de 4-9 cm. Bulbos 13-20 × 11-15 mm, globosos u ovoides, comprimidos, prolongado en un collar de 2-4 cm; catáfilos anchamente ovadolanceolados, agudos o acuminados en el ápice, de color marrón. Hojas basales en la antesis ausentes o hasta 4, lámina 25-55 $\times 0,4-0,8 \mathrm{~cm}$, linear. Hoja caulinar 11-24 $\times 0,4-0,7 \mathrm{~cm}$, ensiforme linear-lanceolada, con su parte basal envolviendo el tallo. Ramas floríferas $25-75 \mathrm{~cm}$ de largo, ramas 2 a 10. Espatas 2 a 6 por rama, 2,8-3,6 $\times$ 0,3-0,4 cm, herbáceas, verdes, 2-valvadas, 1-flora, pedunculadas, pedúnculos $1,5-4,5 \mathrm{~cm}$; valva externa $1,4-1,8 \mathrm{~cm}$, valva interna $2,8-3,5 \mathrm{~cm}$, ambas obtusas en el ápice y terminando en una parte translúcida, con líneas paralelas marrón-oscuro; pedicelo 2,5-4 cm, filiforme. Flores 40-45 mm diámetro, perigonio amarillo, brillantes, con una línea central marrón; concavidad central 8-9 mm diámetro y 5-7 $\mathrm{mm}$ de profundidad. Tépalos externos 24-33 $\times$ 7-8 mm, oblongos, pandurados, amarillo, cóncavo en la base; láminas 17-25 × 10$12 \mathrm{~mm}$, con una línea marrón-oscura central que 
se extiende desde la base hasta la parte media, y con la base con puntitos marrón-oscuro, reflejos y con frecuencia torcidos, ápice truncado o redondeado, apiculado; unguículo 7-8 × 2,5-3 mm de ancho en la base y $8-9 \mathrm{~mm}$ de ancho en el ápice, cuneado, pálido amarillento, translúcido. Tépalos internos 9-10 × 8-9 mm, geniculadorecurvados, la mitad proximal inclinada, después curvada arriba, con el tercio distal incurvado y fuertemente reclinado; $8-9 \mathrm{~mm}$ ancho, amarillas, con una depresión central blanco-crema, cubierto por tricomas lipídicos anaranjados cerca de la base, con una parte lateral más alta, con manchas y líneas paralelas marrón-rojizas; unguículo 5-6 $\times$ 2-2,2 $\mathrm{mm}$ de ancho en la base y 4-4,5 $\mathrm{mm}$ ancho en el ápice, cuneado, pálido amarillento, translúcido, con líneas paralelas marrón-rojizas. Filamentos 2,8-3,4 mm, cónicos, levemente inclinados, purpuro o marrón-rojizo, base engrosada, con manchas o líneas rojizas, unido en la base por 1-2,5 mm; anteras 7-8 $\times$ 3-3,5 mm, oblongas; conectivo 3-3,6 mm de ancho, blanco-crema, con manchas rojizas, tecas oscuras, polen gris-oscuro u ocráceo. Ovario 6-8 × 1,5-2 mm, verde o verdeamarillento, obovado. Estilo 8,5-9,5 $\mathrm{mm}$ de largo, blanquecino en la base y amarillo en el ápice; ramas del estilo 2,5-3 $\mathrm{mm}$ de largo, ascendentes o casi erectas; crestas en el ápice 3, amarillentas, las adaxiales 1,5-2 mm, triangulares, la abaxial 0,5-1 mm, triangular, furcada en el ápice. Cápsula 22-28 $\times$ 4-5 mm, oblonga, conteniendo ca. 85-120 semillas. Semillas 2-2,5 mm de largo, oblongas u obcónicas, marrón-rojizas, anguladas, epidermis con estrías y reticulada.

Distribución geográfica y hábitat. Es una subespecie que habita entre los 50-260 m s.m. en campos bajos y humedales en suelos profundos junto a Axonopus fissifolius, Mecardonia procumbens (Mill.) Small var. flagellaris (Cham. \& Schltdl.) V.C. Souza, Paspalum pumilum Nees y Panphalea blupeurifolia Less., en la parte occidental del Uruguay y en el nordeste de Argentina, (provincias de Entre Ríos y sur de Corrientes). Es la subespecie más frecuente en Salto y Paysandú y ha sido observada creciendo simpátrica con $C$. herbertii subsp. herbertii en el sur de Artigas y Salto, pero se encuentra muy poco representada en las colecciones de los herbarios nacionales.
Etimología. Del latín reflexus (= reflejo), en referencia a los tépalos externos muy reflejos que presenta esta subespecie.

Observaciones. Cypella herbertii subsp. reflexa puede ser reconocida por su hábito más delgado, flores con perigonio amarillo y tépalos externos muy reflejos. Las flores de 40-45 $\mathrm{mm}$ de diámetro presentan tamaño intermedio comparadas a la subsp. brevicristata $34-40 \mathrm{~mm}$ y la subsp. herbertii 45-55 mm. Se trata de una subespecie muy común no encontrándose en estado de amenaza.

\section{Material examinado}

URUGUAY. Artigas, ruta 4, XI-2014 L.P. Deble et al. 15306 (PACA!). Paysandú, 9-XI-2013, L. Eggers et al. 845 (ICN!); Rio Negro, 10-XI-2013, L. Eggers et al. 848 (ICN); Salto, 8-XI-2013, L. Eggers et al. 841 (ICN!); ruta 26, XI-2014 L.P. Deble et al. 15307 (PACA!).

9. Cypella laeta Ravenna, Wrightia 7 (1): 13. 1981 (sect. Nais). TIPO: Argentina, Entre Ríos, Concordia, "Culta in Bonaria ex Bulbis ad Parque San Martín [Parque Rivadávia] pr. Concordiam prov. Entre-Rios Argentinae collectis", P. F. Ravenna 506, XII.1967 (holotipo Herb. Rav., no localizado). Lectotypus (designado por Deble \& Alves 2020: 17) ARGENTINA. Entre Rios: Concordia, Estación Agronómica, 16.I.1927, $A$. Burkart 784 (lectotipo SI!). Figs. 9F-J y 7.

Cypella yatayphila Ravenna, Onira Botanical leaflets 12 (1): 3. 2009. TIPO: Argentina, Entre Ríos, Colón, Parque Nacional El Palmar, 31 $52^{\prime} 29^{\prime \prime} \mathrm{S} 58^{\circ} 12^{\prime} 36^{\prime \prime} \mathrm{W}$, patio de la Intendencia, 15-16.XI.2003, A. A. Cocucci et al. 2926 [=2916]" (holotipo SI!; isotipo CTES!).

Plantas de 13-35 $\mathrm{cm}$ de altura, tallos subterráneos de 5-10 cm. Bulbos 20-40 × 20$35 \mathrm{~mm}$, globosos u ovoides, comprimido, prolongado en un collar de 4-8 cm; catáfilos anchamente ovados, suavemente agudos en el ápice, de color marrón oscuro. Hojas basales en la antesis 1 a 4, lámina 8-16 ×0,2-0,5 cm, linearensiforme. Hoja caulinar en $1 / 3$ basal, 3,5-9,5 $\times$ $0,1-0,3 \mathrm{~cm}$, con su parte basal envolviendo el tallo. 

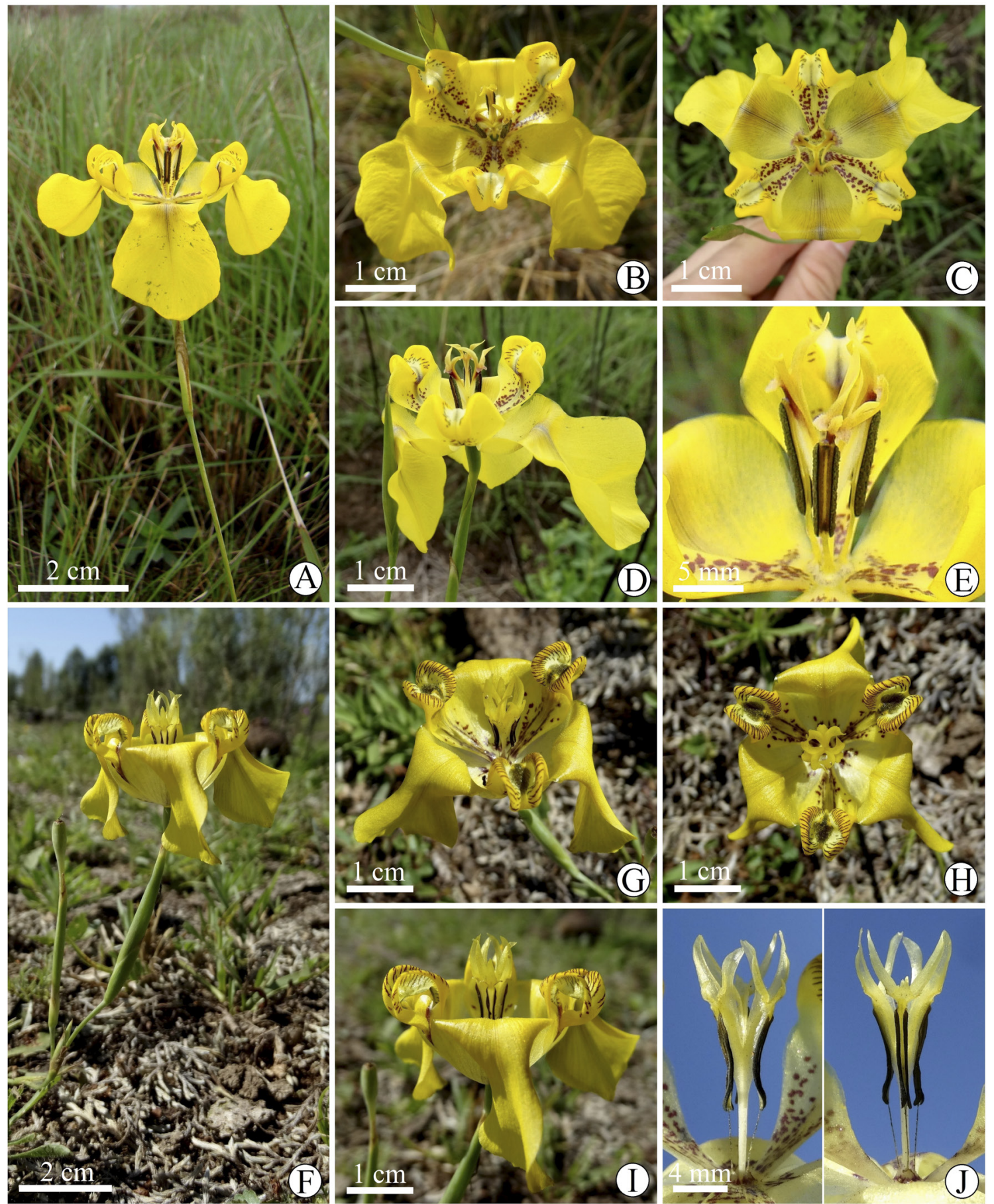

Fig. 9. Cypella laxa (A-E). A, ramo en flor. B, flor, vista oblicua. C, flor vista frontal. D, flor, vista lateral. E, detalle de estambres y estilo, vista frontal. Cypella laeta (F-J). F, ramo en flor. G, flor, vista oblicua. H, flor vista frontal. I, flor, vista lateral. J, detalle de estambres y estilo, vista lateral y frontal. A, D-E, de Deble \& Moreira 19167; B-C, de Deble et al. 13480; F-J, de Deble et al. 14291. Figura en color en la versión en línea http://www.ojs.darwin.edu.ar/ index.php/darwiniana/article/view/921/1221 
Ramas floríferas 11-28 cm de largo, ramas 2 a 4 . Espatas 2 a 4 por rama, 3,3-3,6 $\times 0,3-0,5 \mathrm{~cm}$, herbáceas, verde-amarillentas, pruinosas, 2-valvadas, 2-flora, pedunculadas, pedúnculos $2-4,8 \mathrm{~cm}$; valva externa $1,4-2,2 \mathrm{~cm}$, valva interna 3-3,5 cm, ambas agudas en el ápice y densamente revestida por puntitos y líneas glandulares; pedicelo 2,6-3,8 cm, filiforme. Flores $35-50 \mathrm{~mm}$ diámetro, perigonio amarillo-ocráceo, con manchas púrpuras o purpuro-oscuro y puntitos rojos; concavidad central $25-35 \mathrm{~mm}$ diámetro y $10-15 \mathrm{~mm}$ de profundidad. Tépalos externos 34-40 × 7,5-11 mm, oblongos, pandurados, amarillo-ocráceo, cóncavo en la base; láminas 20-26 × 14-17 mm, amarillo-ocráceo, con una banda central más oscura, con tricomas verdeoliva, erectas en el tercio basal y recurvadas en el ápice; unguículo 7-10 $\times 3-3,5 \mathrm{~mm}$ de ancho en la base y $8-9,5 \mathrm{~mm}$ de ancho en el ápice, cuneado, amarillento, translúcido, con manchas rojizas. Tépalos internos arqueadorecurvados, 17-23 $\times$ 7-9 $\mathrm{mm}$, la mitad proximal inclinada, después curvada arriba, con el tercio distal incurvado y fuertemente reclinado; láminas 7-9 $\mathrm{mm}$ ancho, amarillo-ocrácea, con una depresión central purpuro-oscuro, cubierto por tricomas lipídicos translúcidos encima, con una parte lateral más alta, blanco-crema en la mitad proximal, después amarilla, con líneas paralelas purpuro-oscuro y manchas irregulares en toda su extensión; unguículo $8-10 \times 1,9-2,2 \mathrm{~mm}$ de ancho en la base y 8-8,5 $\mathrm{mm}$ ancho en el ápice, cuneado, amarillento, con líneas y puntitos rojizos. Filamentos 5,8-6,5 $\mathrm{mm}$ de largo, delgados, filiformes, levemente inclinados, ocráceos o marrón, base engrosada, unidos en la base por $0,2-0,5 \mathrm{~mm}$; anteras $6,5-7 \times 1,4-$ $1,8 \mathrm{~mm}$, oblongas; conectivo 0,3-0,5 $\mathrm{mm}$ de ancho, amarillo o blanco-crema, tecas oscuras, polen gris-oscuro u ocráceo. Ovario verde, obovado-oblongo 4-8 $\times$ 2-3 mm. Estilo 7-8 mm de largo; ramas del estilo 6-7 $\mathrm{mm}$ de largo, ascendentes; crestas en el ápice 3, amarillas, las adaxiales 3,5-4 $\mathrm{mm}$, anchamente lanceoladas o falcadas, la abaxial 1-1,5 mm, triangular. Cápsula 10-18 × 6-8 mm, obovado-oblonga, conteniendo ca. 50 semillas. Semillas oblongas u obcónicas, marrón-oscuro, ca. 2 mm de largo, anguladas, epidermis papilosa o estriada.
Distribución geográfica y hábitat. Cypella laeta es una especie endémica en zonas sedimentarias en la Provincia de Entre Ríos, Argentina, y en los departamentos de Paysandú y Salto en Uruguay, donde crece en pastizales junto a Calibrachoa felipponei (Sandwith) Stehmann, Cypella fucata, Frailea castanea Backeb., Portulaca grandiflora Hook. y Stapfochloa canterae (Arechav.) P.M. Peterson, entre los 10-40 m s.m. sobre campos rocosos de origen basáltico del grupo Arapey, formación Itapebí y laderas de arenisca al margen del río Uruguay sobre la formación Guichón (Bossi \& Navarro, 1988; Bossi \& Ferrando, 2001; Bossi \& Schipilov, 2007), sitio del cual no existen colectas por tratarse de una población de pocos individuos al igual que las encontradas en el departamento de Salto.

Etimología. El adjetivo latín laetus significa "alegre" o "feliz" y hace referencia a la belleza de las flores.

Observaciones. La especie es fácilmente reconocida por sus espatas conteniendo dos flores y perigonio de color amarillo-ocre. Puede ser confundida con $C$. discolor, de la cual se diferencia por presentar espatas con pedúnculos largos $2-4,8 \mathrm{~cm}$ vs $0,4-1,8 \mathrm{~cm}$ ramas del estilo más largas 6-7 $\mathrm{mm}$ vs 3-3,5 mm y crestas adaxiales más largas 3,5-4 $\mathrm{mm}$ vs 2,5-3,5 $\mathrm{mm}$. Es la única especie de la sección Nais con dos flores por espata presente en Uruguay. Las otras dos especies que tienen esta característica son C. suffusa Ravenna, endémica de Misiones, Argentina y C. aquatilis Ravenna, del sur de Brasil (centro y norte de Río Grande del Sur, Santa Catarina y suroeste de Paraná).

Cypella laeta es una especie con hábito especifico, en campos rocosos y sus bulbos crecen asociados a guijarros. El área de distribución de la especie sufre de una creciente degradación por el loteo de campos para uso agrícola-ganadero así como el aumento de la silvicultura. Por su reducida distribución geográfica, C. laeta debe ser reconocida como En Peligro según los criterios da IUCN (2019): EN B 1, 2 (a,b,c) + D.

\section{Material examinado}

URUGUAY. Paysandú, camino para la gruta del Padre Pio, 31 28 '17.0S, 5753'23.1 W', 275m, 5-XI-2013, L. P. Deble et al. 14291 (PACA!). 
10. Cypella laxa Ravenna, Wrightia 7 (1): 15. 1981. TIPO: Brasil, Paraná, Guarapuava, "in uliginosis circ. $2 \mathrm{~km}$ a posto Agropecuario mun. Guarapuavae civit" P. F. Ravenna \& G. G. Hatschbach 1008, 3.XII.1969 (holotipo Herb. Rav., no localizado). LECTÓTIPO, designado por Eggers et al. 2019: 752): Brasil, Paraná, Guarapuava, "In uliginosis, circ. 2 $\mathrm{km}$ a Posto Agropecuario mun. Guarapuavae civit. Paranaensis Brasiliae", 3.XII.1969, P. F. Ravenna \& G. Hatschbach 1008 (lectotipo K [K000322475] imagen!). Figs. 9A-E y 7.

Plantas de 55-135 cm de altura, tallos subterráneos de 4-10 cm. Bulbos 5-10 × 5-10 mm, globosos u ovoides, prolongado en un collar de 4-10 cm; catáfilos anchamente ovados, suavemente agudos en el ápice, de color amarronado. Hojas basales en la antesis 1 a 2, lámina 12-45 × 0,06-0,2 $\mathrm{cm}$, angosto linear. Hoja caulinar en $1 / 3$ basal, rígida, $13-54 \times 0,1-0,2 \mathrm{~cm}$, con su parte basal envolviendo el tallo. Ramas floríferas $21-78 \mathrm{~cm}$ de largo, ramas 1 a 2 . Espatas 1 a 2 por rama, 3,4-5 × 0,2$0,3 \mathrm{~cm}$, herbáceas, verde-amarillentas, pruinosas, 2-valvadas, 1-flora, pedunculadas, pedúnculos 4-11 cm; valva externa $1,4-2 \mathrm{~cm}$, valva interna 3,3-5 cm, ambas obtuso mucronadas en el ápice; pedicelo 4,6-5,6 cm de largo, filiforme. Flores $35-50 \mathrm{~mm}$ diámetro, perigonio amarillo-gema, con manchas púrpuras o purpuro-oscuro en la concavidad central; concavidad central $25-35 \mathrm{~mm}$ diámetro y 10-12 $\mathrm{mm}$ de profundidad. Tépalos externos 25-40 × 11-12 mm, obovados u oblongos, pandurados, amarillos, cóncavo en la base; láminas 15-29 $\times 15-18 \mathrm{~mm}$, amarillo, con una banda central más oscura, con tricomas amarillos o dorados, erectas en el tercio basal y recurvadas en el ápice; unguículo 9-11 $\times$ 3-3,5 mm de ancho en la base y 9-10 mm de ancho en el ápice, cuneado, amarillento, translúcido, con manchas marrón-rojizas. Tépalos internos 16-20 × 11-15 mm, arqueado-recurvados, la mitad proximal inclinada, después curvada arriba, con el tercio distal incurvado y fuertemente reclinado; láminas 11-15 $\mathrm{mm}$ ancho, amarilla, con una depresión central purpurea, cubierta por tricomas lipídicos translúcidos encima, con una parte lateral más alta, blanco-crema en la mitad proximal, después amarilla, con líneas paralelas purpureas-oscuras y manchas irregulares en toda su extensión; unguículo $8-10 \times 2,3-2,5 \mathrm{~mm}$ de ancho en la base y 9-10,5 mm ancho en el ápice, cuneado, amarillento, con líneas y puntitos rojizos. Filamentos 2,8-4 mm de largo, delgado, filiforme, levemente inclinados, amarillentos u ocráceos, base engrosada, unido en la base por 0,2-0,3 mm; anteras 7-8,5 × 1,2-1,8 mm, oblongas; conectivo 0,7-0,8 $\mathrm{mm}$ de ancho, amarillo o blanco-crema, tecas oscuras, polen gris-oscuro u ocráceo. Ovario 6-7 $\times$ 2-3 mm, verde, obovado-oblongo. Estilo 6-7 mm de largo; ramas del estilo 4-5 mm de largo, ascendentes; crestas en el ápice 3, amarillas, las adaxiales 3,5-4 mm, anchamente lanceoladas o falcadas, la abaxial 1-1,5 mm, triangular. Cápsula 15-25 × 7-10 mm, obovado-oblonga u oblonga, conteniendo 214-305 semillas. Semillas ca. $2 \mathrm{~mm}$ de largo, cónicas, parduscas, con líneas rojizas, anguladas, epidermis lisa.

Distribución geográfica y hábitat. Cypella laxa es una especie ampliamente distribuida en el sur, sureste y centro-oeste de Brasil, sureste del Paraguay y nordeste de la Argentina y presentemente adicionada a la flora del Uruguay donde fue encontrada en el departamento de Rivera, creciendo únicamente en bañados asociada a Eryngium pandanifolium, Xyris jupicai Rich., Sinningia elatior (Kunth) Chautems, Begonia cucullata Willd., Andropogon lateralis Nees, Hibiscus striatus Cav. y Rhynchospora tenuis sobre suelos de areniscas de la formación Tacuarembó a 120 m s.m. (Bossi \& Navarro, 1988; Bossi \& Ferrando, 2001).

Etimología. Del latín laxus, amplio o ancho en referencia a la forma de la depresión central de las flores.

Observaciones. Cypella laxa es una especie de fácil reconocimiento por su hábito muy esbelto y sobre todo por sus bulbos muy pequeños de color marrón claro. Cypella laxa es morfológicamente afín a Cypella crenata (Vell.) Ravenna que habita solamente en el estado brasileño de Minas Gerais. De las especies uruguayas se asemeja a $C$. rivularis y $C$. charruana; sin embargo, $C$. rivularis tiene bulbos $25-40 \times 20-35 \mathrm{~mm}$ vs $5-10 \times$ 5-10 mm, las hojas son más anchas $0,3-0,7 \mathrm{~cm}$ vs $0,06-0,2 \mathrm{~cm}$ y la forma de las flores muy distinta. 
Cypella charruana posee hojas más anchas 0,2-0,5 $\mathrm{cm}$ vs $0,06-0,2 \mathrm{~cm}$, espatas más anchas $0,4-0,5 \mathrm{~cm}$ vs $0,2-0,3 \mathrm{~cm}$ y flores con tépalos externos con unguículo muy angosto $2-2,5 \mathrm{~mm}$ vs $3-3,5 \mathrm{~mm}$. Es necesario realizar más excursiones con la finalidad de localizar nuevas poblaciones de $C$. laxa y de esa forma evaluar el estado de conservación de la especie en Uruguay, teniendo en cuenta que la misma presenta hábito esbelto y es difícil de encontrar por su presencia en ambientes pantanosos y flores que marchitan próximo a las 10 a.m.

\section{Material examinado}

URUGUAY. Rivera, Paso del Cerro, empalme ruta 5 y 29 , camino a derecha, en los esteros, 8-XI2019, L.P. Deble \& B.P. Moreira 19167 (PACA!). BRASIL. Rio Grande do Sul, Santiago, RS 168, 26-X-2013, L.P. Deble et al. 13480 (PACA!).

\section{Cypella luteogibbosa Deble, Phytotaxa 71} (1): 60. 2012 (sect. Cypella). TIPO: Brasil, Rio Grande do Sul, Quaraí, $28 \mathrm{~km}$ ao sul do trevo para o Passo da Guarda, 19-X-2010, fl., fr., L. P. Deble \& A. S. de Oliveira-Deble 10265 (holótipo: PACA!). Figs. 10A-E y 7.

Plantas de 10-35 cm de altura, tallos subterráneos de 4-10 cm. Bulbos 20-35 × 20-30 mm, globosos $\mathrm{u}$ ovoides, comprimidos, prolongado en un collar de $2-4 \mathrm{~cm}$; catáfilos anchamente ovado-elípticos, agudos o acuminados en el ápice, de color marrón oscuro. Hojas basales en la antesis 2 a 4, lámina 10-26 $\times 0,2-0,5 \mathrm{~cm}$, linear-elíptica. Hoja caulinar $5-15 \times 0,2-0,4 \mathrm{~cm}$, ensiforme elíptica, con su parte basal envolviendo el tallo. Ramas floríferas $10-27 \mathrm{~cm}$ de largo, ramas 2 a 3 . Espatas 2 a 3 por rama, 2,3-3,2 × 0,2-0,3 cm, herbáceas, verdes, 2-valvadas, 1-flora, pedunculadas, pedúnculos $1,8-3 \mathrm{~cm}$; valva externa $1,4-2,2 \mathrm{~cm}$, valva interna 2,5-3 cm, ambas agudas en el ápice y terminando en una parte translúcida, con líneas paralelas naranja-oscuro; pedicelo 2,8-3,2 cm de largo, filiforme. Flores 28-36 mm diámetro, perigonio blanco o blanco-ocráceo; concavidad central 10-12 $\mathrm{mm}$ diámetro y $6-7 \mathrm{~mm}$ de profundidad. Tépalos externo $18-22 \times 7-10 \mathrm{~mm}$, obovados o espatulados, pandurados, blanco-ocráceo, cóncavo en la base; láminas 11-15 × 10-12 mm, con venas oscuras, muy reflejas, con abundantes tricomas ocráceos cerca de la base, ápice truncado o redondeado, apiculado; unguículo 7-9 × 2-2,5 mm de ancho en la base y 7,5-8,5 $\mathrm{mm}$ de ancho en el ápice, anchamente cuneado, blanquecino, translúcido. Tépalos internos 8-9 × 8,5-9 mm, geniculado-recurvados, la mitad proximal inclinada, después curvada arriba, con el tercio distal incurvado y fuertemente reclinado; láminas 8,5-9 $\mathrm{mm}$ ancho, blanca, con una depresión central blanco-crema, cubierto por tricomas lipídicos amarillos cerca de la base, con una parte lateral más alta, en forma de quilla con manchas purpuro-oscuro a negras, parte dorsal con una giba amarilla; unguículo 3,5-4 × 2-2,5 mm de ancho en la base y $4 \mathrm{~mm}$ ancho en el ápice, anchamente cuneado, blanco, con manchas marrón-rojizas. Filamentos 2-2,5 $\mathrm{mm}$ de largo, anchamente obclavado, declinado, blanco-crema o blancorosado, base engrosada, con manchas o líneas rojizas, unido en la base por 0,3-0,4 $\mathrm{mm}$; anteras 3-3,5 $\times$ 0,7-1 mm, obovado-oblongas; conectivo 0,8-1 mm de ancho, blanco-crema, tecas oscuras, polen gris-azulado o cian. Ovario 5-6 × 1,8$2,1 \mathrm{~mm}$, verde o verde-amarillento, obovado. Estilo 7-8 $\mathrm{mm}$ de largo, blanquecino; ramas del estilo 3-4 mm de largo, ascendentes; crestas en el ápice 3, vítreas, las adaxiales 3,4-4,2 mm, lanceoladas, la abaxial $0,5-0,8 \mathrm{~mm}$, triangular, entera o furcada en el ápice. Cápsula 14-21 $\times$ 5-7 mm, oblonga, conteniendo 35-60 semillas. Semillas ca. $2 \mathrm{~mm}$ de largo, oblongas u obcónicas, marrón-rojizas, anguladas, epidermis reticulada.

Distribución geográfica y hábitat. Conocida hasta ahora en el Uruguay en campos rocosos de origen basáltico del grupo Arapey, formaciones Tomás Gomensoro y Curtina, (Bossi \& Navarro, 1988; Bossi \& Ferrando, 2001; Bossi \& Schipilov, 2007) en los departamentos de Artigas y Rivera donde crece entre los 100-320 m s.m. en fisuras junto a Paspalum plicatulum Michx., Lessingianthus brevifolius (Less.) H. Rob., Pfaffia tuberosa (Spreng.) Hicken, Richardia humistrata y Chevreulia sarmentosa y en la cima de cerros de areniscas en el departamentos de Artigas sobre la formación Rivera donde es muy escasa. Además, crece en el suroeste de Río Grande del Sur, Brasil. 

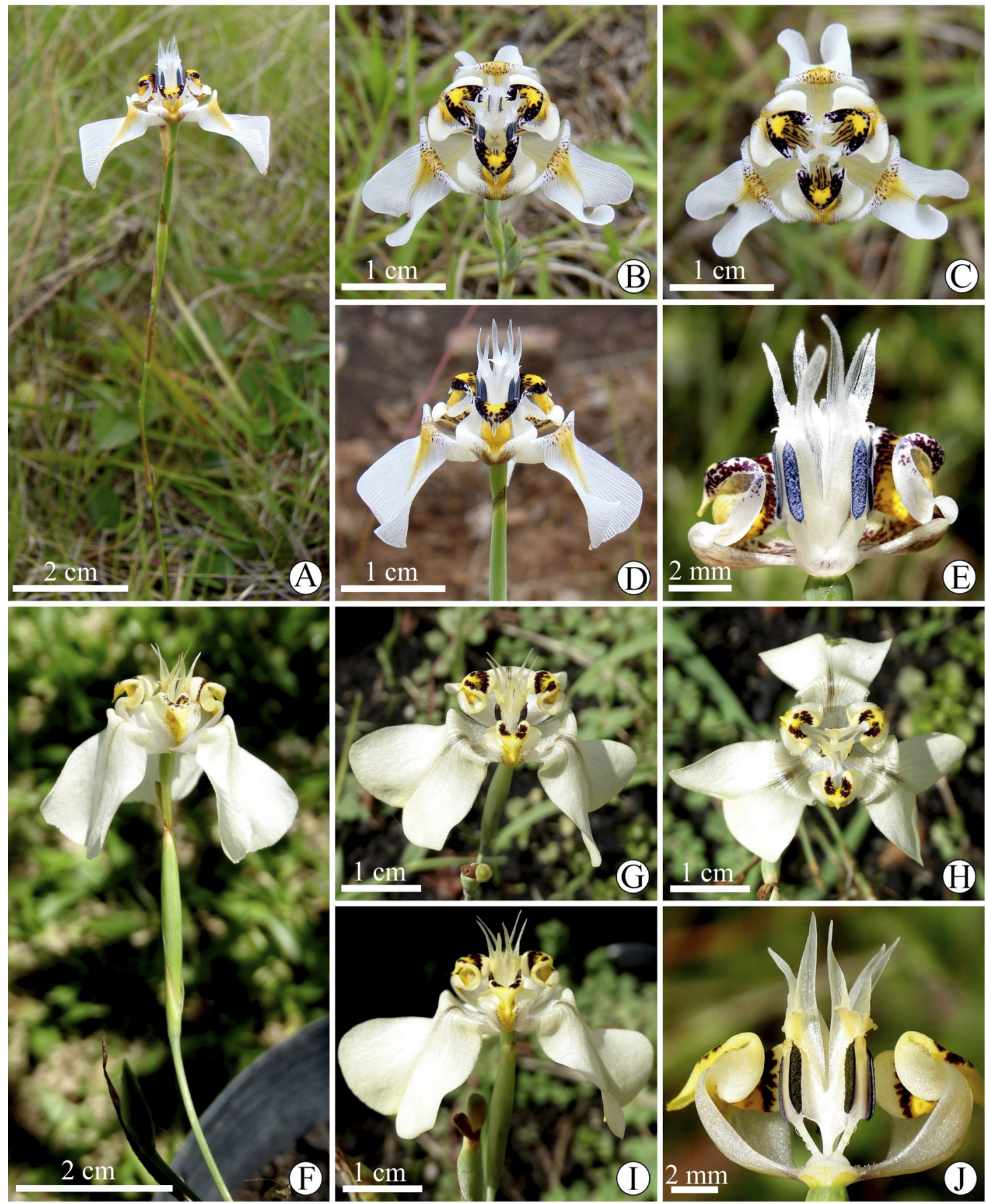

Fig. 10. Cypella luteogibbosa (A-E). A, ramo en flor. B, flor, vista oblicua. C, flor vista frontal. D, flor, vista lateral. $\mathbf{E}$, detalle de estambres y estilo, vista lateral. Cypella osteniana (F-J). F, ramo en flor. G, flor, vista oblicua. H, flor vista frontal. I, flor, vista lateral. J, detalle de estambres y estilo, vista lateral. A-E, de Deble \& Alves 16041; F-J, de Deble et al. 17194. Figura en color en la versión en línea http://www.ojs.darwin.edu.ar/index.php/darwiniana/ article/view/921/1221 
Etimología. Del latín luteus (= amarillo) y gibbosus (= giba o joroba), en referencia a los tépalos internos, que tiene una giba de color amarillo en la parte dorsal que es muy característica.

Observaciones. Cypella luteogibbosa es fácilmente reconocida por sus espatas unifloras, flores con perigonio blanco o blanco-ocráceo y tépalos internos con una joroba de color amarillo. Cypella luteogibbosa se encuentra En Peligro, debido su rareza y amenazas como el sobrepastoreo y explotaciones de canteras para extraer material de rutas (Eggers et al., 2019).

\section{Material examinado}

URUGUAY. Artigas, Artigas, Piedra Pintada, na borda de cerro, 10-XII-2016, L.P. Deble \& F.S. Alves 16041 (PACA!); Artigas, 8 November 2013, L. Eggers et al. 838 (ICN). Rivera, Cañas, entre rocas, fl. blanco-ocráceas, 8-XI-2019, L.P. Deble \& B.P. Moreira 19166 (PACA!).

12. Cypella osteniana Beauverd, Bull. Soc. Bot. Genève ser. 2, 14: 165, 1923. TIPO: Uruguay. Depto. Minas, "loco dicto Verdun, in saxosis, Cypella cf. plumbea Lindley, perigon bräunlichweiss, innere, zurückgebogen gelb, braun marmorirt" 16.IV.1908, C. Osten s.n. [p.p.] (holotipo: MVM!). Figs. 10F-J y 7.

Plantas de 10-25 cm de altura, tallos subterráneos de 3-6 cm. Bulbos 16-30 × 15-25 mm, globosos $\mathrm{u}$ ovoides, prolongado en un collar de $2-4 \mathrm{~cm}$; catáfilos anchamente ovado-lanceolados, agudos o acuminados en el ápice, de color marrón claro o parduzco. Hojas basales en la antesis ausente o 1 a 2, lámina 8-16 × 0,05-0,2 cm, angostamente linear. Hoja caulinar 5-10 × 0,1-0,2 cm, ensiforme elíptica, con su parte basal envolviendo el tallo. Ramas floríferas 8-22 cm de largo, ramas 1 a 4 . Espatas 1 a 4 por rama, 1,9-2,8 × 0,3-0,4 cm, herbáceas, verdes, 2-valvadas, 2-floras, pedunculadas, pedúnculos 0,8 $2,5 \mathrm{~cm}$; valva externa $1-1,8 \mathrm{~cm}$, valva interna $1,9-$ $2,8 \mathrm{~cm}$, ambas levemente agudas hasta obtusas en el ápice y terminando en una parte oscura, con líneas paralelasmarrón-oscuro; pedicelo 1,5-3 cm, filiforme. Flores $25-35 \mathrm{~mm}$ diámetro, perigonio blanco o blanco-ocráceo; concavidad central 10-15 mm de diámetro y 5-6 $\mathrm{mm}$ de profundidad. Tépalos externos obovados, pandurados, 19-24 × 9-12 mm, blancos con nervaduras ocre-oscuro, cóncavo en la base; láminas 11-15 × 14-17 mm, con venas oscuras, suavemente patentes hasta reflejas, con abundantes tricomas ocráceos cerca de la base, ápice redondeado, apiculado; unguículo 7-9 $\times$ 2-2,5 $\mathrm{mm}$ de ancho en la base y 8-9 $\mathrm{mm}$ de ancho en el ápice, cuneado, blanco, translúcido. Tépalos internos geniculado-recurvados, 7-8 $\times 6,5-7,5 \mathrm{~mm}$ longitud, la mitad proximal inclinada, después curvada arriba, con el tercio distal incurvado y fuertemente reclinado; láminas 6,5-7,5 $\mathrm{mm}$ ancho, blanca, con una depresión central blanco-crema, cubierto por tricomas lipídicos amarillos cerca de la base, con una parte lateral más alta, con manchas purpuras hasta purpuro-oscuro; unguículo 3,5-4 $\times$ $1,8-2 \mathrm{~mm}$ de ancho en la base y $3,5 \mathrm{~mm}$ de ancho en el ápice, cuneado, blanco. Filamentos 1,5-2,5 mm de largo, obclavados, declinados, blanco o blancocrema, base engrosada, unido en la base por 0,2$0,3 \mathrm{~mm}$; anteras 3-3,5 × 1,8-2,2 $\mathrm{mm}$, anchamente oblongas; conectivo 1,2-1,6 mm de ancho, blanco, tecas oscuras, polen ocráceo. Ovario 5-6 $\mathrm{mm} \times$ 1,8-2 $\mathrm{mm}$, verde o verde-amarillento, obovado. Estilo 7-8 mm de largo, blanco; ramas del estilo 3-4 mm de largo, ascendentes o patentes; crestas en el ápice 3, vítreas, las adaxiales 3,5-4,5 mm, lanceoladas, la abaxial 0,5-1 mm, triangular, entera o furcada en el ápice. Cápsula 8-14 × 4-6 mm, oblonga, conteniendo 18-35 semillas. Semillas ca. $2 \mathrm{~mm}$ largo, oblongas u obcónicas, comprimidas $\mathrm{y}$ angulosas, marrón-rojizas, epidermis reticulada.

Distribución geográfica y hábitat. Cypella osteniana es endémica del Uruguay, siendo característica de campos rocosos y cerros rocosos en el sur y centro-este del país entre los 20-220 $\mathrm{m}$ s.m. donde crece junto a Schlechtendalia luzulifolia Less., Plantago commersoniana Decne. \& Barnéoud, Oxypetalum nigricans (Decne.) Liede \& Meve, Calea uniflora Less., Acanthostyles buniifolius, Bromus auleticus Trin. ex Nees y Parodia erinacea (Haw.) N.P. Taylor siendo su límite norte de distribución la localidad de Minas de Corrales, en el sur del departamento de Rivera. Los bulbos crecen únicamente en hendiduras de rocas de distintos orígenes y composiciones: anfibolitas de formación Montevideo, cuarcitas de 
formación Cerro Espuelitas, tillitas de formación San Gregorio y areniscas de formación Mercedes, Tacuarembó y Yaguarí (Preciozzi et al., 1985; Bossi \& Navarro, 1988; Poiré et al., 2003).

Etimología. Especie dedicada al botánico alemán Cornelius Osten (1863-1936), quien emigrara a Uruguay en 1886 y trabajara con José Arechavaleta, en el Museo Nacional de Historia Natural de Montevideo.

Observaciones. La especie es reconocida por sus espatas con dos flores y por el perigonio blanco o blanco-ocráceo. Es muy parecida a $C$. luteogibbosa, de la cual se diferencia por presentar espatas 2-floras vs 1-floras, tépalos internos con manchas rojas o purpuras vs. purpuro-oscuras o casi negras y ramas del estilo muy separadas con crestas divergentes vs. ramas del estilo próximas con crestas convergentes.

Cypella osteniana posee una distribución geográfica relativamente amplia, pero sus poblaciones están compuestas por pocos individuos y su hábitat es específico. La minería y silvicultura resultan amenazas directa para la especie por lo que es evaluada como En Peligro según los siguientes criterios de la IUCN (2019): EN B2 a(i,ii,iii,iv) c (i,ii,iii,iv) + D.

Las colecciones A. lombardo s.n. (MVJB 3310 ! MVJB 5945!) indican flores amarillas, sin embargo, todos los demás caracteres coinciden con $C$. osteniana lo que sugiere que es un error de etiqueta o una población con flores de tépalos amarillos.

\section{Material examinado}

URUGUAY. Cerro largo, Cerro de las Cuentas, al costado de vía férrea y pedregal, 29XII-1938, B. Rosengurtt 2788 (MVFA!); en ladera rocosa pratense, 23-II-1938, B. Rosengurtt 2569 (MVFA!). Cerro de las Cuentas, 32॰36'21"S, 5436'53"'W, 24 January 2007, L. P. Deble \& A. $S$. de Oliveira 7911 (SI!). Melo, $17 \mathrm{~km}$ southeast of Melo, 32॰30'56"S, 5404'13"W, 18 February 2006, L. P. Deble \& A. S. de Oliveira 7294 (SI!). Flores, Puntas del Sauce, 19-XI-1894, C. Osten 3176 (MVM 18533!). Lavalleja, III-1924, C. Osten 14164 (MVM!); idem, V-1923, C. Osten 17164 (MVM!); III-1924, G. Herter 14164 (MVM
18532!); ruta 81 em direção a Montes, desde ruta 60, em campo rochoso, $250 \mathrm{~m}, 34^{\circ} 32^{\prime} 44.1^{\prime \prime} \mathrm{S}$ 55'15'17.1W", 11-XI-2013, L. Eggers et al. 858 (ICN 180035!). Montevideo, Atahualpa, “fl. amarillas", 6-II-1926, A. Lombardo s.n. (MVJB 3310!); idem, I-1927, “fl. amarillas", A. Lombardo s.n. (MVJB 5945!). Cerro de Montevideo, ladera sur, 240m al sur de la Fortaleza, 27-XII-2015, F. Haretche 915 (MVJB 29609!). Puntas del Arroyo Miguelete, km 19, camino Mendoza, 22-III-1985, P. Ferrés \& M. Ferrés s.n. (MVFA 17472!). Río Negro, río negro y Arroyo Yapeyú, Estancia El Jabalí, loma pedregosa, 23-X-1997, E. Marchesi s.n. (MVFA 26969!); Los Mellizos, Establecimiento La Nueva Esperanza, 21-XII2006, I. Grela \& F. Haretche (MVJB 26747). Rivera, Minas de Corrales, ruta 29, cerca del empalme para San Fernandina, 4-X-2016, L.P. Deble et al. 17194 (PACA!). Salto, flor blanca, al borde de la carretera, 20-II-1991, P. Izaguirre et al. 20.143 (MVFA!). Tacuarembó, flor blanca, orilla de carretera, basalto, 11-XII-1997, E. Marchesi \& I. Grela s.n. (MVFA 27073!). Treinta y Tres, ruta 8, en rocas cerca de la vía, 27-XII-2016, L.P. Deble \& A.S. Oliveira 17195 (PACA!).

13. Cypella rivularis Chauveau \& L. Eggers, Phytotaxa 174 (1): 36. 2014. TIPO: Brasil, Rio Grande do Sul, Uruguaiana, BR 290,

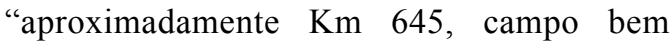
preservado, em baixada, em borda de pequenos riachos, $172 \mathrm{~m}$ ", fl. and fr. 25-XI2013, L. Eggers et al. 869 (holotipo ICN!). Figs. 8F-J y 7.

Plantas de 23-90 cm de altura, tallos subterráneos de $8-25 \mathrm{~cm}$. Bulbos 25-40 × 20$35 \mathrm{~mm}$, oblongos, prolongados en un collar de 5-9 cm; catáfilos anchamente ovado-elípticos, agudos en el ápice, de color marrón claro. Hojas basales en la antesis hasta 7, lámina 21-60 × 0,3$0,7 \mathrm{~cm}$, angostamente linear. Hoja caulinar 6,5$46 \times 0,2-0,6 \mathrm{~cm}$, ensiforme elíptica, con su parte basal envolviendo el tallo. Ramas floríferas $18-80 \mathrm{~cm}$ de largo, ramas 2 a 4 . Espatas 1 a 4 por rama, 3,9-6,8 $\times$ 0,2-0,4 $\mathrm{cm}$, herbáceas, verdes, 2-valvadas, 1-flora, pedunculadas, pedúnculos $2-9 \mathrm{~cm}$; valva externa $1,5-2,2 \mathrm{~cm}$, 
valva interna $3,5-6,7 \mathrm{~cm}$, ambas levemente agudas hasta obtusas en el ápice y terminando en una parte oscura, con líneas paralelas marrónoscuro; pedicelo 3,5-6 cm, filiforme. Flores 50$60 \mathrm{~mm}$ diámetro, perigonio amarillo; concavidad central 20-25 mm diámetro y $10-14 \mathrm{~mm}$ de profundidad. Tépalos externos 35-42 × 15-22 mm, obovados, pandurados, amarillo brillante, con nervaduras amarillas, cóncavo en la base; láminas 24-30 $\times 18-25 \mathrm{~mm}$, con puntitos rojos o marrónrojizos en la mitad basal, suavemente patentes hasta reflejas, con abundantes tricomas amarillodorados cerca de la base, ápice redondeado, apiculado; unguículo 10-12 2 2,5-3 mm de ancho en la base y 11-12 mm de ancho en el ápice, cuneado, amarillo brillante. Tépalos internos 20-25 × 10$14 \mathrm{~mm}$, arqueado-recurvados, la mitad proximal inclinada, después curvada arriba, con el tercio distal incurvado y fuertemente reclinado; láminas 10-14 mm ancho, amarilla, con depresión central blanco-crema, cubierto por tricomas lipídicos amarillos arriba y una parte lateral más alta, con manchas rojas o marrón-rojizas; unguículo 10-14× 2,1-2,4 $\mathrm{mm}$ de ancho en la base y 8,5-10 $\mathrm{mm}$ de ancho en el ápice, cuneado, amarillo. Filamentos 6,4-9,3 mm, lineares, casi erectos, amarillos o amarillo-verdosos, base engrosada, unido en la base por 0,5-1,3 $\mathrm{mm}$; anteras 7,5-9 × 2-2,5 mm, angostamente oblongas; conectivo 1,5-1,9 mm de ancho, amarillento, tecas ocráceas, polen amarillo. Ovario 9-11 $\times 2-2,5 \mathrm{~mm}$, verde o verdeamarillento, obovado. Estilo 10-18 mm de largo, amarillo o amarillo-verdoso; ramas del estilo 4$5 \mathrm{~mm}$ de largo, ascendentes; crestas en el ápice 3, vítreas, las adaxiales 5-7 mm, lanceoladas, la abaxial 1-3 $\mathrm{mm}$, triangular, entera o furcada en el ápice. Cápsula 16-22 × 4-5 mm, oblonga, conteniendo 15-25 semillas. Semillas ca. 2,5$3,5 \mathrm{~mm}$ de largo, oblongas u obcónicas, comprimidas y angulosas, marrón-rojizas, epidermis reticulada.

Distribución geográfica y hábitat. Especie descrita originalmente para el suroeste del estado de Río Grande del Sur, donde fue encontrada en corrientes y arroyos en la municipalidad de Uruguaiana, su distribución geográfica se extiende a Uruguay, donde crece en grietas de rocas basálticas del grupo Arapey, formación
Los Catalanes (Bossi \& Navarro, 1988; Bossi \& Ferrando, 2001; Bossi \& Schipilov, 2007) entre los 100-150 m s.m. junto a Axonopus fissifolius, Eriochloa punctata, Eragrotis cataclasta Nicora, Eleocharis viridans, Cuphea racemosa y Scoparia montevidensis (Spreng.) R.E. Fr. cerca de arroyos y pequeñas corrientes, en campos húmedos y rocosos de la cuenca del Río Cuareim, en el departamento de Artigas.

Etimología. Del latín, rivulum, que es de los ríos, una referencia al hábitat preferencial de la especie, cerca de ríos y corrientes.

Observaciones. Perteneciente a la sección Nais, C. rivularis se diferencia de las demás especies por sus flores de $50-60 \mathrm{~mm}$ de diámetro vs $32-50$ $\mathrm{mm}$ en las restantes especies de la sección, tépalos firmes en textura, de color amarillo-yema con puntitos rojo-oscuro o marrón.

\section{Material examinado}

URUGUAY. Artigas, Arroyo Cuaró Grande, 30 45'19.35"S, 56 45"13.63"W, 16-XI-2014, L. P. Deble et al. 15689 (SI!); Arroyo Carapé, 15-XI2017, L.P. Deble \& al. 16504 (PACA!).

\section{Especies excluidas}

1. Cypella coelestis (Lehm.) Diels, Nat. Pflanzenfam., ed. 2 [Engler \& Prantl] 15a: 498. 1930

$=$ Phalocallis coelestis (Lehm.) Ravenna, Not. Mens. Mus. Nac. Hist. Nat. Santiago 21(249): 9. 1977. Marica coelestis Lehm., Index Sem. (Hamburg) 1826: 17. 1826. Cypella plumbea Lindl., Edward's Bot. Reg. 21

Phalocallis coelestis es reconocida por sus flores azules o lila, con tépalos internos cubierto por tricomas largos en dos bandas laterales. Las ramas del estilo terminan en dos crestas petaloides, que son muy amplias y redondeadas, mientras en Cypella las crestas son tres y agudas. La especie habita en Uruguay en los departamentos de Canelones, Cerro Largo, Maldonado, Rocha, Rivera y Tacuarembó, donde crece en humedales. Además, se extiende a Argentina y sur de Brasil. 
2. Cypella unguiculata (Baker) Roitman \& A. Castillo, Darwiniana 45(2), p. 238. 2007

= Onira unguiculata (Baker) Ravenna, Nordic. J. Bot. 3: 204. 1983. Herbertia unguiculata Baker, Handb. Irid.: 72. 1892. Alophia unguiculata (Baker) Kuntze, Rev. Gen. Pl. 3(2): 304. 1898. Trifurcia unguiculata (Baker) Goldblatt, Brittonia 27(4): 384. 1975. TIPO: BRASIL. Rio Grande do Sul: "Hab. South Brazil, Sello!" F. Sellow s.n. (holotipo: B no visto, isotipo G imagen!).

Especie muy interesante por sus flores grandes que contrastan a su pequeño hábito. Puede ser fácilmente identificada por el color lila de su perigonio, estambres con anteras presentando conectivo muy estrecho, estilo con ramas largas que terminan en una zona estigmática dorsal y las crestas no desarrolladas. La especie es característica de campos rocosos y pedregosos en los departamentos de Artigas, Cerro Largo, Rivera y Tacuarembó, además crece en el sureste de Río Grande del Sur, Brasil.

\section{CONCLUSIONES}

El género Cypella está representado en el Uruguay por trece especies y cinco subespecies: C. alonsoana, C. aurinegra subsp. aurinegra, $C$. aurinegra subsp. atropurpurata, C. charruana, C. discolor, C. exilis, C. fucata, C. guttata, C. herbertii subsp. brevicristata, $C$. herbertii subsp. herbertii, $C$. herbertii subsp. reflexa, C. laeta, C. laxa, C. luteogibbosa, C. osteniana y C. rivularis. Cypella herbertii subsp. herbertii, C. exilis y C. fucata son las especies con mayor distribución geográfica en el Uruguay, ocurriendo en casi todo el territorio. Cypella alonsoana, C. osteniana y C. aurinegra son endémicas de Uruguay, mientras $C$. herbertii subsp. brevicristata habita en la zona fronteriza del departamento de Artigas con el suroeste de Río Grande del Sur (Brasil), y Corrientes y Entre Ríos (Argentina). Cypella laeta habita en el departamento de Salto y Paysandú y en área contiguas en Entre Ríos, Argentina, y finalmente, C. charruana y C. guttata fueron recientemente descritas para el departamento de Artigas y áreas adyacentes en el suroeste del Rio Grande del Sur, siendo también adicionadas en este trabajo al departamento de Rivera.
Las especies C. discolor, C. luteogibbosa y C. rivularis son exclusivas en los departamentos de Artigas y Rivera, mientras C. laxa es una nueva cita, siendo encontrada en campos húmedos en formaciones de arenisca en el departamento de Rivera.

\section{AGRADECIMIENTOS}

Los autores agradecen a Lucía Ifrán, José Luis Antúnez, Gustavo Garabelli, Antolín Peralta y Gustavo Centomo por su hospitalidad y colaboración en los viajes de colecta por el norte de Uruguay así como a Raquel Caggiano y Sebastián Marmol por los aportes referentes a la geología del país.

\section{BIBLIOGRAFÍA}

Baker, J. G. 1877. Systema Iridacearum. Journal of Linnean Society, Botany 16: 61-180. DOI: http://dx.doi. org/10.1111/j.1095-8339.1877.tb00172.x

Baker, J. G. 1892. Handbook of the Irideae. London: George Bells \& Sons, 248 pp. DOI: http://dx.doi.org/10.5962/bhl.title.15431

Barker, C. 2020. World Checklist of Iridaceae. Facilitated by the Royal Botanic Gardens, Kew. Disponible en: http://apps. kew.org/wcsp/ (acceso en enero 2020).

Beauverd, G. 1923. VII. Nouvelles Iridacées de 1'Uruguay. Bulletin de la Société Botanique de Genève, Sér. 2, 14: 163-167.

Beentje, H. 2010. The Kew Plant Glossary: an illustrated dictionary of plant terms. Kew: Royal Botanic Gardens. 160p.

Bossi, J. \& R. Navarro. 1988. Geología del Uruguay. Departamento de publicaciones de la Universidad de la República. Montevideo, Uruguay. 996p.

Bossi, J. \& L. A. Ferrando. 2001. Carta Geológica del Uruguay. Montevideo, Uruguay. Geoeditores. Esc. 1:500.000. Color.

Bossi, J. \& A. Schipilov. 2007. Rocas ígneas básicas del Uruguay. Departamento de publicaciones de la Facultad de Agronomía, Universidad de la República Oriental del Uruguay, Montevideo, Uruguay. 240p.

Chauveau, O.; L. Eggers, T. T. Souza-Chies \& S. Nadot. 2012. Oil-producing flowers within the Iridoideae (Iridaceae): evolutionary trends in the flowers of the New World genera. Annals of Botany 110: 713-729. DOI: http://dx.doi. org/10.1093/aob/mcs134

Deble, L. P.; A. S. de Oliveira \& F. S. da Alves. 2012a. Cypella discolor é redescoberta nos campos do Oeste e Sudoeste do Rio Grande do Sul. In: A. S. de Oliveira, L. P. Deble \& A. L. S. Leão, Bioma Pampa: Ambiente $\times$ Sociedade, pp. 68-76. Ediurcamp, Bagé. 
Deble, L. P.; J. B. Rodriguez, A. S. de Oliveira \& T. G. L. Filipini. 2013. Taxonomic Novelties in Calydorea Herbert (Iridaceae: Tigridieae) II. Balduinia 40: 1-8. DOI: http:// dx.doi.org/10.5902/23581980

Deble, L. P.; F. S. Alves, A. González \& A. S. de Oliveira. 2015a. Three new species of Cypella (Iridaceae) from South America, and taxonomic delimitation of C. suffusa Ravenna. Phytotaxa 236 (2): 101-120. DOI: http://dx.doi. org/10.11646/phytotaxa.236.2.1

Deble, L. P.; F. S. Alves \& A. S. de Oliveira. 2015b. Three new species of the genus Cypella (Iridaceae, Tigridieae). Darwiniana, nueva serie 3: 235-253. DOI: http://dx.doi. org/10.14522/darwiniana.2015.31.666

Deble, L. P.; F. S. Alves \& A. S. de Oliveira. 2016. Calydorea minuana, a new species of Iridaceae from Río de La Plata Grasslands, South America. Phytotaxa 253: 81-89.

Deble, L. P. 2017. La identificación de Cypella exilis Ravenna (Iridaceae). Balduinia 56: 27-34.

Deble, L. P. \& F. S. Alves. 2017a. The type of Cypella herbertii subsp. brevicristata Ravenna (Iridaceae: Tigridieae). Balduinia 56: 20-26.

Deble, L. P. \& F. S. Alves. 2017b. Taxonomic novelties for the genus Cypella (Iridaceae): new species, synonymies and nomenclatural types. Kew Bulletin, Kew 72: 41.

Deble, L. P. \& F. S. Alves. 2020. Cypella (Iridaceae) What do we know about the diversity of the genus? Balduinia 66: 2-27.

Eggers, L.; R. Marchioretto, T. T. Souza-Chies \& O. Chauveau. 2019. A taxonomic synopsis of Cypella (Iridaceae) in Brazil. Acta Botânica Brasílica 33: 741-769.

Elizalde, G.; W. Eugui, J. Verdesio, M. Stapff \& J. Telechea. 1970. Carta Geológica del Uruguay: segmento Aceguá Sector XXX. Departamento de publicaciones. Universidad de la República, Montevideo, Uruguay. Esc. 1: 100.000, 126 p. Color.

Goldblatt, P. \& J. C. Manning. 2008. The Iris Family. Natural History and Classification. Portland: Timber Press. 290 pp.

IUCN Standards and Petitions Committee. 2019. Guidelines for Using the IUCN Red List Categories and Criteria, version 14. IUCN Species Survival Commission. IUCN, Gland, Switzerland and Cambridge, UK. Disponible en http://www. iucnredlist.org/documents/RedListGuidelines.pdf

Johnston, I. M. 1938. The species of Sisyrinchium in Uruguay, Paraguay and Brazil. Journal of the Arnold Arboretum 19: 376-401.

Klatt, F. W. 1862. Specimen e familia Iridacearum. Linnaea 31: 533-570.

Klatt, F. W. 1871. Irideae: 510-548. In: Martius, C. F. P. von \& A. G. Eichler (eds.). Flora Brasiliensis 3 (1). Wolf, C. et fil. $\&$ Minsinger, S., Munich.
Poiré, D. G.; P. D. González, J. M. Canalicchio \& R. F. García. 2003. Litoestratigrafía y estromatolitos de la sucesión sedimentaria precámbrica de la cantera mina Verdún, Minas, Uruguay. Revista de la Sociedad Uruguaya de Geología. Publicación Especial $N^{\circ} 1$. II Taller sobre la estratigrafía del precámbrico del Uruguay: 108-123.

Preciozzi, P. F.; P. J. Sportuno, M. W. Heinzen \& K. P. Rossi. 1985. Carta Geológica del Uruguay a escala 1: 500.000 . Programa Cartografía Geológica del Uruguay, Montevideo, $90 \mathrm{pp}$.

Ravenna, P. 1965. Notas sobre Iridaceae II. Boletín de la Sociedad Argentina de Botánica 10 (4): 311-322.

Ravenna, P. 1981a. A submerged new species of Cypella (Iridaceae), and a new section for the genus (s.str.). Nordic Journal of Botany 1: 489-492.

Ravenna, P. 1981b. Eight new species and two new subspecies of Cypella (Iridaceae). Wrightia 7 (1): 13-21.

Ravenna, P. 1983. Catila and Onira, two new genera of South America Iridaceae. Nordic Journal of Botany 3: 197-205. DOI: http://dx.doi.org/10.1111/j.1756-1051.1983.tb01065.x

Ravenna, P. 1984. The delimitation of Gelasine (Iridaceae)and G. uruguaiensis sp. nov. from Uruguay. Nordic Journal of Botany 4: 347-350.

Ravenna, P. F. 1989. A new species of Herbertia from SE South America. Nordic Journal of Botany 9: 55-56.

Roitman, G. G. \& J. A. Castillo. 2004. Novedades en el género Cypella (Iridaceae). Boletín Sociedad Argentina de Botánica 38: 337-339.

Roitman, G. \& J. A. Castillo. 2005. Calydorea alba (Iridaceae, Tigridieae) a new species from Uruguay. Boletín de la Sociedad Argentina de Botánica 40 (3-4): 311-312.

Roitman, G. \& J. A. Castillo. 2007. Novedades taxonómicas y nomenclaturales para la flora vascular del cono sur de Sudamérica: nuevas combinaciones en Iridaceae. Darwiniana 45: 236-241.

Roitman, G; I. Maza \& J. A. Castillo. 2008. Iridaceae, in F. O. Zuloaga, O. Morrone \& M. J. Belgrano (eds.), Catálogo de las Plantas Vasculares del Cono Sur, vol. I. Monographs in Botany from the Missouri Botanical Garden 107: 423-453.

Sweet, R. 1822. Herbertia pulchella. Plaited leaved Herbertia. The British Flowers Garden 3: pl. 222.

Thiers, B. 2020 [Continuosly updated]. Index Herbariorum: A global directory of public herbaria and associated staff. New York Botanical Garden's Virtual Herbarium. http:// sweetgum.nybg.org/science/ih/

Wright, C. H. 1907. Herbertia amatorum. In Decades Kewensis. Plantarum Novarum in Herbario Hortii Regi Conservatarum. Bulletin of Miscellaneous Information Kew 8: 321-322. 